\title{
Review on benefits, toxicity, challenges, and future of graphene-based face masks in the prevention of COVID-19 Pandemic
}

\author{
Siyanand Kumar Chaudhary ${ }^{1}$, Nabina Chaudhary ${ }^{2}$, Rahul Chaudhary ${ }^{2}$, Narendra Kumar Chaudhary ${ }^{\text {Corresp. } 1}$ \\ 1 Department of Chemistry, Mahendra Morang Adarsh Multiple campus, Biratnagar (Tribhuvan University), Biratnagar, Province-1, Nepal \\ 2 Dhaka Central International Medical college, University of Dhaka, Dhaka, Bangladesh \\ Corresponding Author: Narendra Kumar Chaudhary \\ Email address: chem_narendra@yahoo.com
}

The COVID-19 pandemic caused by SARS-CoV-2 has become a global public health concern. Recently, vaccines have been developed to treat this infectious disease.

However, these newly developed vaccines are not widely available and not suitable for all age groups. In such circumstances, it is wise to wear personal protective equipment (PPE) such as masks, gloves, and gowns to better protect against COVID-19. Face masks have long been recommended as a means of preventing respiratory infections. However, inappropriate use of masks may undermine their effectiveness. The antimicrobial and antiviral properties of graphene have sparked interest in the development of medical devices such as face masks, gloves, and gowns with extra filtering ability to curb the effects of the coronaviruses. Their hydrophobicity, nanosize, large surface area, high electrical and thermal conductivities, and virulence are notable features that reduce the transmission of viruses from person to person via respiratory routes. Graphene-enhanced face masks are intended to encourage travelers to wear them at work and during recreational activities. Moreover, graphene can pose health hazards if inhaled during respiration. In this review, we summarize the current status of graphene and its promising applications for combating COVID-19. Additionally, this review aims to explore the quality of this biomaterial and possible suggestions for the better and safer use of graphene structured respirators. 


\title{
Review on benefits, toxicity, challenges, and future of graphene-based face masks in the prevention of COVID-19 Pandemic
}

\author{
Siyanand Kumar Chaudhary ${ }^{1}$, Nabina Chaudhary ${ }^{2}$, Rahul Chaudhary ${ }^{2}$, and Narendra \\ Kumar Chaudhary ${ }^{1}$ \\ ${ }^{1}$ Department of Chemistry, Mahendra Morang Adarsh Multiple Campus, (Tribhuvan University), \\ Biratnagar, Nepal \\ ${ }^{2}$ Dhaka Central International Medical College, Dhaka University, Bangladesh \\ Corresponding Author: Narendra Kumar Chaudhary, chem_narendra@yahoo.com
}

\begin{abstract}
The COVID-19 pandemic caused by SARS-CoV-2 has become a global public health concern. Recently, vaccines have been developed to treat this infectious disease. However, these newly developed vaccines are not widely available and not suitable for all age groups. In such circumstances, it is wise to wear personal protective equipment (PPE) such as masks, gloves, and gowns to better protect against COVID-19. Face masks have long been recommended as a means of preventing respiratory infections. However, inappropriate use of masks may undermine their effectiveness. The antimicrobial and antiviral properties of graphene have sparked interest in the development of medical devices such as face masks, gloves, and gowns with extra filtering ability to curb the effects of the coronaviruses. Their hydrophobicity, nanosize, large surface area, high electrical and thermal conductivities, and virulence are notable features that reduce the transmission of viruses from person to person via respiratory routes. Graphene-enhanced face masks are intended to encourage travelers to wear them at work and during recreational activities. Moreover, graphene can pose health hazards if inhaled during respiration. In this review, we summarize the current status of graphene and its promising applications for combating COVID-19. Additionally, this review aims to explore the quality of this biomaterial and possible suggestions for the better and safer use of graphene structured respirators.
\end{abstract}

Keywords: COVID-19, Graphene, Face mask, Personal protective equipment, Hydrophobic

\section{INTRODUCTION}

The current COVID-19 pandemic, caused by the SARS-CoV-2 virus, has become the most debated infectious disease of the $21^{\text {st }}$ century. It poses an unprecedented threat to human health, food habits, travel routes, financial resources, and the work environment (Buonsenso et al., 2021; Guan et al., 2020; Huizar et al., 2020; Shaikh, 2021; Varma et al., 2021). According to the WHO's last updated COVID-19 record (by January 11, 2022), 308,458,509 confirmed cases, 5,492,595 confirmed deaths, and 9,138,211,378 vaccine doses administered have been recorded worldwide. Although the number of deaths per day has decreased, COVID-19 has not been fully controlled and we are bound to follow precautionary measures to prevent its spread. Many countries have declared complete control over COVID-19, but they are still preparing for a worse situation, as they are more likely to mutate and develop new variants. The early stages of COVID-19 were panic, and we were looking for options to stop its spread. Physical distancing, maintenance of well-ventilated rooms, avoidance of crowds, sanitizing hands, coughing into bent 
elbows or tissues, restricting travel, and wearing face masks have been strongly recommended by WHO as preliminary precautions to prevent their spread (Bazaid et al., 2020; Dzisi and Dei, 2020; Matuschek et al., 2020; Morawska et al., 2020). New variants of the coronavirus species are still emerging with some novel features that create confusion regarding their control. Recently, a tidal wave of new COVID-19 strains, Omicron (B.1.1.529), has forced the international community to declare a state of emergency. Most frontline healthcare workers, as well as the elderly and immunocompromised individuals, are vulnerable to the COVID-19 pandemic. Even vaccinated individuals are at high risk of immune system impairment. The use of face masks is a promising approach to reduce the spread of respiratory diseases such as 2019nCoV in affected areas (Abd-Elsayed and Karri, 2020; Howard et al., 2021; Stutt et al., 2020; WHOc, 2020; Youpei Yan et al., 2021). A face mask is part of a non-pharmaceutical intervention that creates a specific barrier to reduce the transmission of respiratory pathogens. Based on the current scenario of wearing masks as respiratory protection equipment, four types of facemasks, such as homemade cloth masks, surgical masks, N95 receptors, and activated carbon masks, are ubiquitous (Ji et al., 2020; Ramírez-Guerrero, 2021; Tirupathi et al., 2020). Despite some shortcomings in the mechanism of action, recent research suggests that medical (surgical masks) and nonmedical (homemade cloth masks, N95 receptors) face masks are very effective in providing a superficial level of protection against SARS-CoV-2 transmission (Ji et al., 2020; Karmacharya et al., 2021; Long et al., 2020; Sharma et al., 2020). Therefore, for the defense against the COVID-19 scare, face masks have entered the vast area of the market (Chua et al., 2020; Missoni et al., 2021). The projected inclined figure of the number of masks indicates the need for sufficient raw materials to produce masks in large quantities (Cumbler et al., 2021; Park et al., 2019; Worby and Chang, 2020). The market value of face masks is rapidly increasing, and the desire to offer superior quality filtration in portable respirators has encouraged researchers and the production sectors to explore new materials. Researchers are trying to find a material that can filter air more quickly and efficiently than the materials currently available in face masks (Das et al., 2020; Parlin et al., 2020; Shanmugam et al., 2021).

Natural and synthetic polymer fibers are frequently used as filtering agents in respirators. They are found in various respirators, including surgical face masks and fabric masks (Akduman, 2021; Armentano et al., 2021). Polypropylene, polyurethane, polycarbonate, and polyethylene are examples of synthetic polymers used as filtering agents in respirators (Ogbuoji et al., 2021; $\mathrm{Pu}$ et al., 2018). In addition, cellulose, micro cellulose, and nanocellulose are natural fibers with different morphologies that are used to form a filtering membrane of face masks to prevent the entry of pathogens into the respiratory tract (Garcia et al., 2021). Owing to their surface and bulk properties, such as water permeability, hydrophilicity, and resistance to biofouling, cellulose nanomaterials have demonstrated promising prospects for the development of membranes for viral filtration applications (Junter and Lebrun, 2017; Trache et al., 2020; Wang et al., 2013). The large pore size of non-woven natural and synthetic polymer-based face masks, compared to the sizes of pathogens, particles, respiratory droplets, and aerosols, is the principal cause of the reduction in the mechanical process of air filtration (Jung et al., 2014; Salter, 2021; Santos et al., 2020; Tcharkhtchi et al., 2021). Therefore, finer materials with pores smaller than those of pathogens, particulates, and droplets are essential, and there is a demand for creating excellent respirators. 
92 Graphene ensures better respiration when embedded in air-filtering membranes of respirators 93 (Gope et al., 2021; Goswami et al., 2021). It has a two-dimensional structure in which $\mathrm{sp}^{2}$ 94 hybridized carbons are arranged hexagonally in a honeycomb lattice (Fig. 1). Because of its 95 single layer of carbon atoms, it has a very high surface-to-mass ratio. A key feature of graphene 96 is its large surface area, which makes it suitable for interfacial interactions (Innocenzi and Stagi, 97 2020; Nguyen et al., 2019; Pranno et al., 2020; Reina et al., 2021; Zou et al., 2016). The high 98 electrical conductivity, large surface area, photocatalytic activity, and hydrophobic nature of 99 graphene have attracted the interest of many researchers for the design of high-quality respirators 100 (Cheng et al., 2017; Kasbe et al., 2021; Maqbool et al., 2021; Stanford et al., 2019). As they are 101 extremely hydrophobic and microporous, they do not allow aerosols, water droplets, particles, or pathogens to remain in the outer layer of the respirators for long periods (Fig. 2). In addition, graphene-derived nanomaterials such as graphene oxide (GO) and reduced graphene oxide (RGO) contain - $\mathrm{COOH},-\mathrm{OH},-\mathrm{CONH}_{2}$, and $-\mathrm{C}-\mathrm{OH}$ moieties (Fig. 1), which effectively interact with bacterial and viral cell membranes and rupture their outer envelopes. The pore size of the graphene membrane (5.7-25.2 $\AA$ ) is smaller than the virus size $(0.05-0.14 \mu \mathrm{m})$ (Jayaweera et al., 2020). Therefore, it has a greater tendency to serve as a selectively permeable membrane to separate the pernicious SARS-CoV-2 (Castelletto and Boretti, 2021; Liu et al., 2015). It is a light-sensitive material that can absorb $2.3 \%$ of the incident visible light (Li et al., 2019). The amount of light absorbed can increase the temperature of graphene by more than $56{ }^{\circ} \mathrm{C}$, which is sufficient to expel SARS-CoV-2 from the outer surface of graphene-coated face masks within 30 min (Yang and Wang, 2020). Exposure of functionalized graphene face masks to sunlight for 10 min can increase the antibacterial efficiency by $8 \%$ to $99.99 \%$ (Huang et al., 2020). Additionally, the sanitization and washing of graphene-loaded face masks are less tedious than those of other mask types. Furthermore, the eco-friendly and reusable features of graphene-based surgical and nonsurgical masks appear to be popular among users.

Several graphene functionalized materials have shown antibacterial properties, and their effectiveness in killing bacteria is encouraging (Krishnamoorthy et al., 2012; Li et al., 2014; S. Liu et al., 2011; Perreault et al., 2015; Yang et al., 2017; Zhang and Tremblay, 2020; Zhao et al., 2013). Despite the enormous potential of graphene in a wide variety of biomedical applications, such as drug delivery, chemotherapeutic agents, electron transport systems, enzyme-induction, and bone defect repair (Abbasi et al., 2016; Behbudi, 2020; Dhinakaran et al., 2020; Du et al., 2020; Kumar and Chatterjee, 2016; Perini et al., 2020), only a few studies have addressed its application in virus filtering membranes (Barbhuiya et al., 2020; Matharu et al., 2020; Musico et al., 2014). An overview of face masks made from graphene and its derivatives is presented in this paper, highlighting their antimicrobial characteristics to reduce the spread of infectious and fatal diseases such as COVID-19. Moreover, this review addresses the benefits, challenges, and future outlook of masks functionalized with graphene and its derivatives.

\section{SURVEY METHODOLOGY}

The literature referenced in this study was systematically reviewed and searched using PubMed, Google Scholar, and various internet websites. We set no time limits for the search. A manual search was performed to collect appropriate literature. This search was conducted based on title, author name, journal scope, and year of publication. The keywords used to search the literature were "face mask and types" or "face mask and graphene" or "face mask and COVID-19". 


\section{AIR FILTRATION BY GRAPHENE FACE MASK}

Face masks are considered safety gear since they protect the respiratory system from airborne droplets and particles. Developing a mask with adequate comfort and high efficacy for removing bio-aerosols, airborne particles, microorganisms, and the particulate matter requires the selection of novel materials and an understanding of the filtering mechanisms in various environments. The face mask efficiency can be affected by many factors, including the inherent properties of the material, chemical composition of the filter, fiber thickness in the filter membrane, and packaging density (Konda et al., 2020; Leung et al., 2020). Moreover, many external factors, such as gravitational force, air velocity, electrostatic charge, frequency of respiration, relative humidity, temperature, loading time, and particle interception, contribute to disturbances in air filtration (Rengasamy et al., 2018; Tcharkhtchi et al., 2021). Scientists have used natural and synthetic polymers for decades to make standard-grade face masks. Owing to the failure of polymer-based face masks to meet the standard values and norms, attempts have been made to replace them with graphene, graphene oxide, reduced graphene oxide, and metal-based nanoparticles.

Graphene is a hydrophobic material that is used in face masks to quickly remove respiratory droplets (Deng et al., 2021). Aerosolized particles ranging in size from 1 to $10 \mathrm{~mm}$ were trapped inside the pores of the outer layer of a traditional face mask. Graphene-based face masks have a unique filtration system that prevents water droplets from attaching to their surfaces and remaining there for an extended period. To verify the filtering efficiency of the $3 \mathrm{D}$ printed face mask, Goswami et al. used functionalized graphene to fabricate filtering membranes of 20, 10, and $3 \mathrm{~mm}$ made from polypropylene (Goswami et al., 2021). Aerosol particles containing viruses and bacteria were allowed to pass through three layers of the membrane: the outer and inner layers without graphene, and the middle layer with graphene, and they found that bacteria and viruses were trapped more in the middle layer. They explained the air filtration process in three ways, based on the materials used and the results obtained. Initially, they believed that graphene had a sharp edge similar to a nano blade that would tear apart the virus' spike protein. Additionally, they hypothesized that electrostatic interactions with living particles may have played a significant role in trapping them, and third, they suggested that the pore size and hydrophobicity of functionalized graphene may have resulted in superior filtration.

A key part of the material is the functional groups of activated graphene oxide, which improves the filtration process (Chung et al., 2021; Rhazouani et al., 2020; Song et al., 2015). In contrast to pristine graphene, graphene oxide and reduced graphene oxide interact more rapidly with the outer lipoprotein layer of bacteria and viruses as they pass through the different layers of the face mask. As bacteria interact rapidly with graphene oxide, other factors such as breathing speed, germ size, and droplet diffusion do not influence how well it filters the air. Furthermore, the addition of graphene oxide to the filtering membrane of the face mask increases the charge density and has a stronger electrostatic effect on microorganisms. Donskyi et al. developed a platform to investigate the electrostatic interactions between functionalized graphene and herpes simplex virus type 1 (HSV-1) (Donskyi et al., 2019). Their study showed that electrostatic forces were the primary driving force behind the virus trapping. Therefore, graphene-based face masks are believed to provide the maximum protection against disease-causing microbiological particles by acting as excellent filters. 
184

185

186

187

188

189

190

191

192

193

194

195

196

197

198

199

200

201

202

203

204

205

206

207

208

209

210

211

212

213

214

215

216

217

218

219

220

221

222

223

224

225

226

227

228

229

Pal et al. measured the filtration efficiency of laser-induced graphene face masks in light (Pal et al., 2021). Light is the main source of photothermal energy that is used to heat the filtering membrane of the face mask. Exposure of face masks to light with a wavelength of $1085 \mathrm{~nm}$ for 15-20 minutes improves filtering efficiency by $99.98 \%$. Therefore, the filtration of air depends not only on the materials used in the membrane, such as graphene nanoparticles but also on the light source used. Lin et al. evaluated the performance of a face mask using the hydrophobicity of graphene material (Lin et al., 2021). Graphene nanosheet-embedded carbon face masks are believed to exhibit excellent performance in air filtration owing to the hydrophobic nature of graphene.

\section{RECENT ADVANCES IN GRAPHENE-BASED FACE MASKS AND BENEFITS}

Recently, interest in graphene-derived 2D nanomaterials such as nanoporous graphene, graphene oxide (GO), reduced graphene oxide (RGO), graphene quantum dots (GQDs), and other graphene-derived materials has increased significantly (Catania et al., 2021; Jiang et al., 2021; Saleh and Fadillah, 2019; Yuxin Yan et al., 2021). These materials are particularly well suited for various ionic sieves, molecular separation, desalination, gas-phase separation, dialysis, hemofiltration, ultra-filtration, water sterilization, sensors, protein separation, viral extraction, and other biomedical applications (Ali et al., 2020, 2019; Thebo et al., 2018). Studies have also demonstrated the synergistic effect of graphene when used in air filtration masks. However, there are very few commercially available graphene-functionalized nanofiber respirators. Face masks would be effective and acceptable only if aerosolized particles are promptly prevented from entering the respiratory tract.

To ensure superior air filtration in respiratory devices, designers must be knowledgeable about the best practices for seeding, polishing, coating, and synthesizing graphene nanoparticles on the nanofibers. Of the many approaches used to seed graphene nanoparticles on a polymer matrix, electrospinning is one of the most versatile and viable. Electrospinning is used to disperse nanoparticles into ultrafine nanofibers with minimal diameters and produce very fine fibers. This is a very reliable method for storing electrical charges in membranes to improve their air filtering performance (Bortolassi et al., 2019; Li et al., 2018; Zhang et al., 2020). Goswami et al. (2021) fabricated a 3D-printed face mask from polylactic acid and coated it with functionalized graphene ink, and measured the virus arresting, capturing, and filtering efficiencies of the mask. This result was exciting and supported the use of functionalized graphene as a filtering and antibacterial agent.

Graphene, a material with antimicrobial and antiviral properties, has increased the interest of the scientific community in investigating its use in preventive measures, detection, and diagnosis of COVID-19 (Damiati et al., 2021; Mojsoska et al., 2021; Payandehpeyman et al., 2021; Pinals et al., 2021; Raval et al., 2020; Torrente-Rodríguez et al., 2020). Graphene-based face masks are newly developed biocompatible medicinal weapons that seem worthy of facing the COVID-19 pandemic. What makes the graphene face masks extraordinary compared to others is shown in Fig. 3. The antibacterial, antistatic, large surface area, sharp edge, photosensitivity, and electrical superconducting nature of graphene nanomaterials are well suited for designing a shielding membrane in face masks and provide a lot of benefits to face mask holders (Fig. 4). Private companies, BonBouton have developed reusable, non-disposable, electrothermally and 
230 photothermally self-sterilizing, and rechargeable graphene face masks with a functional 231 graphene-infused film that can quickly block viruses from getting inside the respiratory trachea 232 (Maqbool et al., 2021). To reduce the pain stacked and mourning situation of the COVID-19 233 pandemic, ZEN Graphene Solution Ltd. and Graphene Composite Ltd. (GC) have also developed 234 a graphene-based composite ink for manufacturing mouth-nose-covering devices and other 235 personal protective equipment (Gope et al., 2021). Using silver and graphene nanoparticle 236 composite inks, they have modified the working mechanism of earlier cotton- and textile-based 237 face masks, which can now efficiently disable SARS-CoV-2 and influenza A and B virus strains 238 (Chaudhary et al., 2021). Planar TECH and IDEATI have also manufactured graphene-coated cotton fabric 2 AM face masks (Gope et al., 2021; Maqbool et al., 2021). Moreover, Goswami and his coworkers have successfully developed and tested a graphene-based 3D-printed facial protection device active against the SARS-CoV-2 virus (Goswami et al., 2021). From the imperial findings, they have inferred that the working principle of the face mask to filter the virus is quite interesting. Likewise, Directa Plus has also used thin atom allotropes of carbon in face masks extracted from graphite to reduce the spread of viral diseases. A skin-tested hypoallergenic $\mathrm{G}+$ mask can offer consumers a range of benefits to protect themselves and others from viral infections (Lea, 2020).

Zhong et al. reported a dual-mode laser fabrication technique for depositing graphene onto temperature-sensitive surgical masks (Zhong et al., 2020). They found that functionalized graphene face masks with super hydrophobic surfaces offered enhanced protection against coronaviruses from respiratory droplets. Furthermore, Shan et al. revealed that electrothermal graphene-modified masks (GMMs) exhibited good performance in preventing particulate matter and viruses from entering the nose. The findings also showed that GMM is far more efficient than the photothermal face mask for purging breathing air (Shan et al., 2020). The most attractive features of the graphene-engineered face masks are their fast-charging capabilities, ability to maintain a temperature of $80{ }^{\circ} \mathrm{C}$ by supplying $3 \mathrm{~V}$ power for $5 \mathrm{~h}$, and reusability and biodegradability. Currently, researchers are well-versed in the many valuable characteristics of graphene. Some researchers have used the unique properties of graphene, such as photosensitivity, to create photothermally self-sterilizing and reusable face masks to reduce the financial and environmental costs associated with the subsequent use of disposable face masks. Graphene nanosheet-embedded carbon (GNEC) film face masks are perfect examples of ways to meet the necessary conditions for improving air filtration quality (Lin et al., 2021). Another private company, Medisevo, claimed that their graphene-based face mask developed by them could filter $98 \%$ of COVID-19 particles. Medisevo evaluated graphene face masks using the medical face mask standards from the American Society for Testing and Materials (Sandle, 2021). LIGC Technology has developed a face mask called the "Guardian G-Volt" made from laser-induced microporous graphene. The originality of this facemask is that it maintains an electrical charge to kill the microbes trapped in the filter, effectively blocking $99 \%$ of contaminants with sizes greater than $0.3 \mu \mathrm{m}$. The graphene face mask G1 Wonder, developed by Nanometric Materials Pvt. Ltd. with a composite membrane of graphene and silver nanoparticles, can kill 99\% of bacteria and viruses (Moore, 2021). Laboratory tests have shown that graphene-silver, a composite membrane made from a collection of microscopic razor-sharp blades of graphene with a high electrically charged potential, has the power to break, open, and destroy bacterial and viral cells. Therefore, masks can prevent COVID-19 transmission by preventing the virus from passing through the mask membrane. Table 1 reports the different 276 types of graphene face masks and their empirically justified outstanding air-filtering features. In 
277

278

279

280

281

282

283

284

285

286

287

288

289

290

291

292

293

294

295

296

297

298

299

300

301

302

303

304

305

306

307

308

309

310

311

312

313

314

315

316

317

318

319

320

321

322

addition, graphene face masks can act as antimicrobial agents even after 10 washes (Ray and Bandyopadhyay, 2021). This is a unique features of this mask, that is not present in many trivial face masks. Other notable features of the graphene-enhanced face masks are shown in Fig. 5. Consequently, the users have numerous advantages. Laser-induced graphene face masks have several excellent physical and chemical mechanisms for fighting SARS-CoV-2 infections (Fig. 4) (Pal et al., 2021).

Graphene-modified face masks can be sterilized using photothermal or electrothermal energy, which is a remarkable feature, not found in surgical masks like N95, FFP3, P100, KN 95, and N99 masks. Owing to its high electrostatic charge retention capacity, it is several times more effective in filtering air than other popular face masks. Furthermore, graphene face masks minimize the use of non-biodegradable materials, thereby ensuring a clean and pollution-free environment. The free electrons of graphene nanoparticles are used to trap positively charged bacteria and viruses in face masks (De Maio et al., 2021; Seifi and Reza Kamali, 2021). Their high electrical conductivity and the flow of electrons from graphene-based materials cause oxidative stress in bacteria and viruses. As a result, protein denaturation and the destruction of cellular components occur rapidly. Furthermore, the mutual Van der Waals attraction between the embedded graphene nanomaterials and the germs in the droplets prevents the spread of microorganisms from person to person via air roots (Kumar et al., 2019). The electrical conductivity of graphene-derived nanomaterials also supports biosensors in detecting, trapping, inactivating, and preventing viruses from spreading. Several studies have emphasized the importance of graphene in the manufacture of sensors as a virus detection agent in clinical settings (Bardhan et al., 2021; Jung et al., 2010; F. Liu et al., 2011; Seo et al., 2020). Furthermore, good electrical conductivity boosts charging speed. Thermal energy also plays an important role in the denaturation of the S-protein and the inactivation of the virus. Thermal exposure of the virus to temperatures of $75^{\circ} \mathrm{C}$ for $3 \mathrm{~min}, 65^{\circ} \mathrm{C}$ for $5 \mathrm{~min}$, and $60{ }^{\circ} \mathrm{C}$ for $20 \mathrm{~min}$ left no option for its survival.

\section{LIMITATIONS, CHALLENGES, AND THE RISK OF USING GRAPHENE FACE MASKS}

As graphene-functionalized face masks are gaining popularity owing to the dire situation of the COVID-19 pandemic, the attention of many researchers has turned to safety awareness, exploring the potential dangers of graphene-seeded respiratory masks (Fadeel et al., 2018). Many analysts believe that such face masks can significantly disrupt the spread of the COVID-19 pandemic by breaking the chain of virus transmission from one infected person to another. A mask containing graphene and its derivatives may cause long-term adverse effects on the user's skin, vital respiratory, circulatory, excretory, and digestive organs (Arvidsson et al., 2013). The lungs may be damaged when grapheme particles reach them after breathing through a mask made of graphene filters. A scientific report has shown that inhalation of graphene nanoparticles can pose serious unexpected risks to lung tissues and blood circulation (Fig. 6) (Ingle et al., 2013; Schinwald et al., 2012; Wang et al., 2016). Based on empirical results, the ability of graphene and its derivatives to inhibit the activation of living cells and the circulation of blood is dose and particle size-dependent (Mukherjee et al., 2018). An experimental study conducted by Zhang et al. found a decrease in metabolic activity with $0.1 \mathrm{mg} / \mathrm{L}$ graphene in mice, but no effect with a $0.01 \mathrm{mg} / \mathrm{L}$ concentration (Zhang et al., 2010). Mice exposed to aerosolized graphene

Peer) Mat. Sci. reviewing PDF | (MATSCI-2021:10:66874:1:1:NEW 15 Jan 2022) 
environments develop lung damage, inflammation, lung granulomas, pulmonary edema, and persistent lung injury (Das et al., 2020; Parlin et al., 2020). Inhalation of graphene in mice caused more severe lung injury than asbestos inhalation in humans. Although it helps reduce the number of COVID-19 patients, the effects of graphene on the cellular level of living organisms are considered hazardous rather than benign. The toxicity of graphene nanomaterials at the cellular level is summarized in Table 2.

Li et al. exposed the skin of some selected people in vitro to a suspended graphene atmosphere and found that the plasma membrane invasion of primary human keratinocytes is due to the aggregation of few-layer graphene-derived material on the dermal layer (Li et al., 2013). Therefore, it is thought that this may also be a possible cause of keratinocytes in people who wear graphene, graphene oxide, or reduced graphene oxide integrated respirators. If masks structured with graphene and its derivatives are worn continuously for a long time, the possibility of nanoparticle adsorption into the skin of the mask covering the area increases (Schinwald et al., 2012). Thus, long-term use of graphene has the potential to cause skin allergies and damage epidermal cells. The effects of different GO panels (lateral dimension: 871-1678 nm; thickness: $1 \mathrm{~nm}-10 \mathrm{~nm}$ ) and graphene sheets (average lateral dimensions: $4312 \mathrm{~nm}$; thickness: up to $10 \mathrm{~nm}$ ) on fibroblast skin were evaluated by Liao et al. (Liao et al., 2011). Their results demonstrated that graphene is more invasive and lethal to dermal cells than graphene oxide because it tends to aggregate within the cells. The MTT method, widely used to assess the toxicity of nanomaterials in cell culture has demonstrated that the metabolic activity of PC12 cells decreases in a concentration-dependent manner after $24 \mathrm{~h}$ of exposure to graphene nanoparticles. Along with promising results, graphene nanoparticles are highly cytotoxic, and the cytotoxicity of nanoparticles varies based on particle dimensions. Furthermore, the toxicity of graphene-based nanoparticles became more apparent in studies of histopathological changes elicited after exposing mice to graphene aerosol environments for five days $(6 \mathrm{~h}$ per day). Histopathological inspection successful explained the rupture of macrophage cells in the presence of 3.05 and 10.1 $\mathrm{mg} / \mathrm{m}^{3}$ graphene (Ma-Hock et al., 2013).

As a source of material for manufacturing of graphene impregnated face masks, graphene nanoparticles may be risky, unrealistic, and perilous (Farahani et al., 2020; Palmieri and Papi, 2020; Zhou and Gao, 2014). Over the past few decades, numerous scientific investigations have alerted investors, researchers, material scientists, chemists, pharmacists, and mask producers to the risks associated with using graphene and its derivatives for multidisciplinary purposes. Several studies have highlighted the harmful effects of graphene and its products on the endocrine, reproductive, immune, nervous, gastrointestinal, and other physiological systems of animals, including humans (Kucki et al., 2017; Orecchioni et al., 2017; Rajakumari et al., 2020; Ramal-Sanchez et al., 2021; Shin et al., 2015). The negative impact of nanographene materials on aquatic, marine, and terrestrial animals and plants suggests that graphene toxicity depends significantly on its concentration and particle size. Some studies have revealed the carcinogenic activities of graphene-based materials (Banerjee, 2016). The toxicity of graphene was also influenced by other physicochemical parameters, as shown in Fig. 5. Exposure of graphene oxide at varying concentrations to the protozoan Euglena gracilis further demonstrated the toxic effect of graphene oxide in the aquatic environment. $\mathrm{Hu}$ et al. discovered that when Euglena gracilis was exposed to graphene oxide at a concentration of $2.5 \mathrm{mg} \mathrm{L}^{-1}$ for $96 \mathrm{~h}$, it had devastating effects. This concentration increases the level of malondialdehyde, which reduces the growth rate 
of E. gracilis and causes oxidative stress (Hu et al., 2015). Additionally, some research has revealed the perilous consequences of graphene-based materials on the marine environment. An experiment with Artemia salina showed that the availability of graphene oxide in water at a concentration of $1 \mathrm{mg} \mathrm{ml}^{-1}$ affects the swimming behavior and survival of its larvae (Lu et al., 2018). Graphene derivatives, such as graphene oxide (GO), quantum dot particles, and reduced graphene oxide (RGO), have also been found to severely affect the metabolic activity, photosynthesis, germination, seedling, growth rate, and flowering of plants (Jastrzębska et al., 2012; Xu et al., 2020; Zhang et al., 2015, 2021). Consequently, graphene-based face masks are considered an unhealthy practice in the manufacture of medical protective equipment such as goggles, gloves, aprons, shoes, and filter membranes.

According to recent reports, the Canadian government has issued an awareness notice from Health Canada declaring that graphene-based face masks can endanger the health of users (Cheng et al., 2021). For a certain month, in Canada, graphene-based face masks were prohibited from being used. Additionally, the director of the French hospital asked people to stop using face masks that included biomass graphene as the elementary material in the filtering membrane until detailed reports of this face mask were obtained. Owing to the lack of comprehensive studies and insufficient evidence to define graphene as a protective material for use in face masks, suggesting that people use graphene engineered face masks for protection purposes would not be appropriate.

\section{FUTURE OUTLOOK}

Graphene and its derived materials improve inappropriate and less efficient personal protective equipment (PPE) containing cotton, silk, chiffon, flannel-based woven, and non-woven fibrous face masks. Graphene is a promising material for enhancing the filtering efficiency of traditional clothing, surgical, non-surgical, and N95 face masks. Recently graphene nanomaterials have been introduced in the production of air-breathing filter membranes to guarantee the superior quality of air purification. Major private companies developing large-scale production of graphene face masks to meet global demand are First Graphene, Planar Tech, Zen Graphene Solutions, and Graphene Composites (GC). Recently, many graphene-related face masks are still in the testing phase, which is why no statistical information is available regarding the positive progress of graphene-related masks. Owing to insufficient information about the scope, demand, challenges, and response to graphene-related face masks; it is difficult to immediately estimate the pros and cons of graphene-fabricated face masks. We believe that the future of graphenebased face masks remains unclear. The incredible power of this face mask to eliminate respiratory droplets, particulate matter, toxic pollutants, bacteria, viruses, pathogens, and aerosolized microorganisms indicates that graphene face masks could play a game-changing role in the future when people face the upcoming waves of the COVID-19 pandemic. However, the possibility of getting sick due to the inhalation of graphene nanoparticles from integrated graphene face masks poses a serious threat that could jeopardize its future scope. Moreover, the restricted use of graphene masks in some countries due to toxicity and dangerous effects on the wearer's cellular level suggests that the use of this personal protective equipment may be worthwhile to some extent (Arvidsson et al., 2018; Fadeel et al., 2018). It is believed that the future of graphene-related face masks is difficult to pinpoint and that portraying them as friends or foes is uncertain. 


\section{CONCLUSION AND FUTURE PERSPECTIVES}

Graphene is an exciting material that may offer multiple benefits for establishing effective mitigation strategies to improve healthcare services against SARS-CoV-2. It is a suitable nanomaterial for embedding coated clothing in PPE, face masks, and gloves to make medical devices more manageable, and efficiently inhibit the spread of SARS-CoV-2. It is used to manufacture mouth-nose-covering masks using the latest technology. Many masks made by obsolete mechanization are useless for filtering small aerosols, ranging in size from $10 \mathrm{~nm}$ to 10 $\mu \mathrm{m}$, whereas face masks related to graphene can filter such ultra-fine particles with excellent success. Hence, graphene-enhanced face masks receive hopeful responses from the users. Several charismatic aspects, such as simplicity of use, auto sterilization, ultra filtration of aerosol particles, reusable type, quick charging process, hydrophobic nature, not suffocating while breathing, durability, and cost-effectiveness, have made it very popular among people who are being hunted by the contagious SARS-CoV-2 virus. However, the interaction of graphene nanoparticles with viable cells and biochemical is considered unsuitable and dangerous to the human body. Although the toxicity of graphene nanoparticles varies depending on the concentration, the number of layers, surface charge density, purity, exposure time, stability, and particle size, even a minor presence of this nanomaterial inside the body can lead to serious chronic diseases, such as cancer. Reports have also shown that its interaction with microphagous cells can weaken the immune system of our body. Hence, we believe that the use of grapheneenhanced face masks is unfriendly. Therefore, there should be a surplus of investigations and studies on the use of such materials before commercialization.

\section{ADDITIONAL INFORMATION AND DECLARATION}

\section{Funding}

The authors received no funding for this work.

\section{Competing Interests}

The authors declare that there are no competing interests.

\section{Author Contributions}

- Siyanand Kumar Chaudhary conceived and designed the study, analyzed the data, prepared figures and/or tables, authored or reviewed the drafts of the paper, and approved the final draft.

- Nabina Chaudhary conceived and designed the study, analyzed the data, authored or reviewed drafts of the paper, and approved the final draft.

- Rahul Chaudhary conceived and designed the study, analyzed the data, performed the computation work, authored or reviewed drafts of the paper, and approved the final draft.

- Narendra Kumar Chaudhary conceived and designed the study, performed the computational work, prepared figures and/or tables, authored or reviewed drafts of the paper, and approved the final draft.

\section{Data Availability}

The following information was supplied regarding data availability: 
This is a literature review article.

462

463

464

465

466

467

468

469

470

471

472

473

474

475

476

477

478

479

480

481

482

483

484

485

486

487

488

489

490

491

492

493

494

495

496

497

498

499

500

501

502

503

504

505

506

\section{REFERENCES}

Abbasi, E., Akbarzadeh, A., Kouhi, M., Milani, M., 2016. Graphene: synthesis, bio-applications, and properties. Artif. Cells, Nanomedicine Biotechnol. 44, 150-156. https://doi.org/10.3109/21691401.2014.927880

Abd-Elsayed, A., Karri, J., 2020. Utility of substandard face mask options for health care workers during the COVID-19 pandemic. Anesth. Analg. 131, 4-6. https://doi.org/10.1213/ANE.0000000000004841

Akduman, C., 2021. Cellulose acetate and polyvinylidene fluoride nanofiber mats for N95 respirators. J. Ind. Text. 50, 1239-1261. https://doi.org/10.1177/1528083719858760

Ali, A., Aamir, M., Thebo, K.H., Akhtar, J., 2020. Laminar graphene oxide membranes towards selective ionic and molecular separations: challenges and progress. Chem. Rec. 20, 344354. https://doi.org/10.1002/tcr.201900024

Ali, A., Pothu, R., Siyal, S.H., Phulpoto, S., Sajjad, M., Thebo, K.H., 2019. Graphene-based membranes for CO2 separation. Mater. Sci. Energy Technol. 2, 83-88. https://doi.org/10.1016/j.mset.2018.11.002

Armentano, I., Barbanera, M., Carota, E., Crognale, S., Marconi, M., Rossi, S., Rubino, G., Scungio, M., Taborri, J., Calabrò, G., 2021. Polymer materials for respiratory protection: processing, end use, and testing methods. ACS Appl. Polym. Mater. 3, 531-548. https://doi.org/10.1021/acsapm.0c01151

Arvidsson, R., Boholm, M., Johansson, M., de Montoya, M.L., 2018. “Just carbon": ideas about graphene risks by graphene researchers and innovation advisors. Nanoethics 12, 199-210. https://doi.org/10.1007/s11569-018-0324-y

Arvidsson, R., Molander, S., Sandén, B.A., 2013. Review of potential environmental and health risks of the nanomaterial graphene. Hum. Ecol. Risk Assess. 19, 873-887. https://doi.org/10.1080/10807039.2012.702039

Banerjee, A.N., 2016. Prospects and challenges of graphene-based nanomaterials in nanomedicine. Glob. J. Nanomedicine 1. https://doi.org/10.19080/gjn.2016.01.555552

Barbhuiya, N.H., Singh, S.P., Makovitzki, A., Narkhede, P., Oren, Z., Adar, Y., Lupu, E., Cherry, L., Monash, A., Arnusch, C.J., 2020. Virus inactivation in water using laserinduced graphene filters. ChemRxiv 1-11.

Bardhan, N.M., Jansen, P., Belcher, A.M., 2021. Graphene, carbon nanotube and plasmonic nanosensors for detection of viral pathogens: opportunities for rapid testing in pandemics like COVID-19. Front. Nanotechnol. 3, 1-15. https://doi.org/10.3389/fnano.2021.733126

Bazaid, A.S., Aldarhami, A., Binsaleh, N.K., Sherwani, S., Althomali, O.W., 2020. Knowledge and practice of personal protective measures during the COVID-19 pandemic: A crosssectional study in Saudi Arabia. PLoS One 15, 1-14. https://doi.org/10.1371/journal.pone.0243695

Behbudi, G., 2020. Mini review of graphene oxide for medical detection and applications. Adv. Appl. NanoBio-Technologies 1, 63-66.

Bhattacharjee, S., Joshi, R., Chughtai, A.A., Macintyre, C.R., 2019. Graphene modified multifunctional personal protective clothing. Adv. Mater. Interfaces 6, 1-27. https://doi.org/10.1002/admi.201900622 
507

508

509

510

511

512

513

514

515

516

517

518

519

520

521

522

523

524

525

526

527

528

529

530

531

532

533

534

535

536

537

538

539

540

541

542

543

544

545

546

547

548

549

550

551

552

Bortolassi, A.C.C., Nagarajan, S., de Araújo Lima, B., Guerra, V.G., Aguiar, M.L., Huon, V., Soussan, L., Cornu, D., Miele, P., Bechelany, M., 2019. Efficient nanoparticles removal and bactericidal action of electrospun nanofibers membranes for air filtration. Mater. Sci. Eng. C 102, 718-729. https://doi.org/10.1016/j.msec.2019.04.094

Buonsenso, D., Roland, D., De Rose, C., Vásquez-Hoyos, P., Ramly, B., Chakakala-Chaziya, J.N., Munro, A., González-Dambrauskas, S., 2021. Schools closures during the COVID-19 pandemic. Pediatr. Infect. Dis. J. 40, E146-E150. https://doi.org/10.1097/INF.0000000000003052

Castelletto, S., Boretti, A., 2021. Advantages, limitations, and future suggestions in studying graphene-based desalination membranes. RSC Adv. 11, 7981-8002. https://doi.org/10.1039/d1 ra00278c

Catania, F., Marras, E., Giorcelli, M., Jagdale, P., Lavagna, L., Tagliaferro, A., Bartoli, M., 2021. A review on recent advancements of graphene and graphene-related materials in biological applications. Appl. Sci. 11, 1-21. https://doi.org/10.3390/app11020614

Chaudhary, V., Royal, A., Chavali, M., Yadav, S.K., 2021. Advancements in research and development to combat COVID-19 using nanotechnology. Nanotechnol. Environ. Eng. 6, 1-15. https://doi.org/10.1007/s41204-021-00102-7

Cheng, L., Guo, W., Cao, X., Dou, Y., Huang, L., Song, Y., Su, J., Zeng, Z., Ye, R., 2021. Laserinduced graphene for environmental applications: Progress and opportunities. Mater. Chem. Front. 5, 4874-4891. https://doi.org/10.1039/d1qm00437a

Cheng, M.M., Huang, L.J., Wang, Y.X., Tang, J.G., Wang, Y., Zhao, Y.C., Liu, G.F., Zhang, Y., Kipper, M.J., Belfiore, L.A., Ranil, W.S., 2017. Recent developments in graphenebased/nanometal composite filter membranes. RSC Adv. 7, 47886-47897. https://doi.org/10.1039/c7ra08098k

Chua, M.H., Cheng, W., Goh, S.S., Kong, J., Li, B., Lim, J.Y.C., Mao, L., Wang, S., Xue, K., Yang, L., Ye, E., Zhang, K., Cheong, W.C.D., Tan, B.H., Li, Z., Tan, B.H., Loh, X.J., 2020. Face masks in the new COVID-19 normal: materials, testing, and perspectives. Research 2020, 1-40. https://doi.org/10.34133/2020/7286735

Chung, H.C., Nguyen, V.G., Kim, C.U., Do, H.Q., Park, B.K., Park, Y.H., Song, D.S., Kong, A., Ryu, J.C., Kang, K.S., 2021. Application of nano-graphene oxide as nontoxic disinfectant against alpha and betacoronaviruses. Vet. Med. Sci. 7, 2434-2439. https://doi.org/10.1002/vms3.584

Cumbler, E., Wittig, M., Jacobson, N., McClain, H., Treat, A., Radin, J., Stowell, S., Harry, E., 2021. Contingency planning for healthcare worker masks in case of medical supply chain failure: Lessons learned in novel mask manufacturing from COVID-19 Pandemic. Am. J. Infect. Control 000, 1-6. https://doi.org/10.1016/j.ajic.2021.07.018

Damiati, S., Sopstad, S., Peacock, M., Akhtar, A.S., Pinto, I., Soares, R.R.G., Russom, A., 2021. Flex printed circuit board implemented graphene-based DNA sensor for detection of SARSCoV-2. IEEE Sens. J. 21, 13060-13067. https://doi.org/10.1109/JSEN.2021.3068922

Das, O., Neisiany, R.E., Capezza, A.J., Hedenqvist, M.S., Försth, M., Xu, Q., Jiang, L., Ji, D., Ramakrishna, S., 2020. The need for fully bio-based facemasks to counter coronavirus outbreaks: A perspective. Sci. Total Environ. 736, 139611. https://doi.org/10.1016/j.scitotenv.2020.139611

De Maio, F., Palmieri, V., Babini, G., Augello, A., Palucci, I., Perini, G., Salustri, A., Spilman, P., De Spirito, M., Sanguinetti, M., Delogu, G., Rizzi, L.G., Cesareo, G., Soon-Shiong, P., Sali, M., Papi, M., 2021. Graphene nanoplatelet and graphene oxide functionalization of 
face mask materials inhibits infectivity of trapped SARS-CoV-2. iScience 24, 102788. https://doi.org/10.1016/j.isci.2021.102788

Deng, W., Sun, Y., Yao, X., Subramanian, K., Ling, C., Wang, H., Chopra, S.S., Xu, B. Bin, Wang, J.X., Chen, J.F., Wang, D., Amancio, H., Pramana, S., Ye, R., Wang, S., 2021. Masks for COVID-19. Adv. Sci. $2102189, \quad 1-30$. https://doi.org/10.1002/advs.202102189Dhinakaran, V., Lavanya, M., Vigneswari, K., Ravichandran, M., Vijayakumar, M.D., 2020. Review on exploration of graphene in diverse applications and its future horizon. Mater. Today Proc. 27, 824-828. https://doi.org/10.1016/j.matpr.2019.12.369

Do, J., Alba, H., De, E., Marcos, R., 2020. Interactions of graphene oxide and graphene nanoplatelets with the in vitro Caco-2 / HT29 model of intestinal barrier 1-15. https://doi.org/10.1038/s41598-020-59755-0

Donskyi, I.S., Azab, W., Cuellar-Camacho, J.L., Guday, G., Lippitz, A., Unger, W.E.S., Osterrieder, K., Adeli, M., Haag, R., 2019. Functionalized nanographene sheets with high antiviral activity through synergistic electrostatic and hydrophobic interactions. Nanoscale 11, 15804-15809. https://doi.org/10.1039/c9nr05273a

Du, Z., Wang, C., Zhang, R., Wang, X., Li, X., 2020. Applications of graphene and its derivatives in bone repair: advantages for promoting bone formation and providing realtime detection, challenges and future prospects. Int. J. Nanomedicine 15, 7523-7551. https://doi.org/10.2147/IJN.S271917

Dzisi, E.K.J., Dei, O.A., 2020. Adherence to social distancing and wearing of masks within public transportation during the COVID 19 pandemic. Transp. Res. Interdiscip. Perspect. 7, 100191. https://doi.org/10.1016/j.trip.2020.100191

Fadeel, B., Bussy, C., Merino, S., Vázquez, E., Flahaut, E., Mouchet, F., Evariste, L., Gauthier, L., Koivisto, A.J., Vogel, U., Martín, C., Delogu, L.G., Buerki-Thurnherr, T., Wick, P., Beloin-Saint-Pierre, D., Hischier, R., Pelin, M., Candotto Carniel, F., Tretiach, M., Cesca, F., Benfenati, F., Scaini, D., Ballerini, L., Kostarelos, K., Prato, M., Bianco, A., 2018. Safety assessment of graphene-based materials: focus on human health and the environment. ACS Nano 12, 10582-10620. https://doi.org/10.1021/acsnano.8b04758

Farahani, M., Rezaei-Tavirani, M., Zali, H., Hatamie, S., Ghasemi, N., 2020. Systems toxicology assessment revealed the impact of graphene-based materials on cell cycle regulators. J. Biomed. Mater. Res. - Part A 108, 1520-1533. https://doi.org/10.1002/jbm.a.36923

Figerez, S.P., Patra, S., Rajalakshmi, G., Narayanan, T.N., 2020. Graphene oxide-based rechargeable respiratory masks. Oxford Open Mater. Sci. 1, 1-9. https://doi.org/10.1093/oxfmat/itab003

Garcia, Rosilei A., Stevanovic, Tatjana, Berthier, Joelle, Njamen, Guy, Tolnai, Balazs, Achim, A., 2021. Cellulose, nanocellulose, and antimicrobial materials for the manufacture of disposable face masks: a review. Bioresour. 16(2), 16, 4321-4353. https://doi.org/DOI: 10.15376/biores.16.2.Garcia

Gope, D., Gope, A., Gope, P.C., 2021. Mask material: challenges and virucidal properties as an effective solution against coronavirus SARS-CoV-2. Open Heal. 1, 37-50. https://doi.org/10.1515/openhe-2020-0004

Goswami, M., Yadav, A.K., Chauhan, V., Singh, N., Kumar, S., Das, A., Yadav, V., Mandal, A., Tiwari, J.K., Siddiqui, H., Ashiq, M., Sathish, N., Kumar, S., Biswas, D., Srivastava, A.K., 2021. Facile development of graphene-based air filters mounted on a 3D printed mask for COVID-19. J. Sci. Adv. Mater. Devices 6, 407-414. https://doi.org/doi: 
Guan, D., Wang, D., Hallegatte, S., Davis, S.J., Huo, J., Li, S., Bai, Y., Lei, T., Xue, Q., Coffman, D.M., Cheng, D., Chen, P., Liang, X., Xu, B., Lu, X., Wang, S., Hubacek, K., Gong, P., 2020. Global supply-chain effects of COVID-19 control measures. Nat. Hum. Behav. 4, 577-587. https://doi.org/10.1038/s41562-020-0896-8

Howard, J., Huang, A., Li, Z., Tufekci, Z., Zdimal, V., van der Westhuizen, H.M., von Delft, A., Price, A., Fridman, L., Tang, L.H., Tang, V., Watson, G.L., Bax, C.E., Shaikh, R., Questier, F., Hernandez, D., Chu, L.F., Ramirez, C.M., Rimoin, A.W., 2021. An evidence review of face masks against COVID-19. Proc. Natl. Acad. Sci. U. S. A. 118, 1-12. https://doi.org/10.1073/pnas.2014564118

Hu, C., Wang, Q., Zhao, H., Wang, L., Guo, S., Li, X., 2015. Ecotoxicological effects of graphene oxide on the protozoan Euglena gracilis. Chemosphere 128, 184-190. https://doi.org/10.1016/j.chemosphere.2015.01.040

Huang, L., Xu, S., Wang, Z., Xue, K., Su, J., Song, Y., Chen, S., Zhu, C., Tang, B.Z., Ye, R., 2020. Self-reporting and photothermally enhanced rapid bacterial killing on a laser-induced graphene mask. ACS Nano 14, 12045-12053. https://doi.org/10.1021/acsnano.0c05330

Huizar, M.I., Arena, R., Laddu, D.R., 2020. The global food syndemic: The impact of food insecurity, malnutrition and obesity on the healthspan amid the COVID-19 pandemic. Prog. Cardiovasc. Dis. 64, 19-22. https://doi.org/DOI: 10.1016/j.pcad.2020.07.002

Ingle, T., Dervishi, E., Biris, A.R., Mustafa, T., Buchanan, R.A., Biris, A.S., 2013. Raman spectroscopy analysis and mapping the biodistribution of inhaled carbon nanotubes in the lungs and blood of mice. J. Appl. Toxicol. 33, 1044-1052. https://doi.org/10.1002/jat.2796

Innocenzi, P., Stagi, L., 2020. Carbon-based antiviral nanomaterials: Graphene, C-dots, and fullerenes. A perspective. Chem. Sci. 11, 6606-6622. https://doi.org/10.1039/d0sc02658a

Jastrzębska, A.M., Kurtycz, P., Olszyna, A.R., 2012. Recent advances in graphene family materials toxicity investigations. J. Nanoparticle Res. 14. https://doi.org/10.1007/s11051012-1320-8

Jaworski, S., Strojny-Cieślak, B., Wierzbicki, M., Kutwin, M., Sawosz, E., Kamaszewski, M., Matuszewski, A., Sosnowska, M., Szczepaniak, J., Daniluk, K., Lange, A., Pruchniewski, M., Zawadzka, K., Łojkowski, M., Chwalibog, A., 2021. Comparison of the toxicity of pristine graphene and graphene oxide, using four biological models. Materials (Basel). 14, 4250. https://doi.org/10.3390/ma14154250

Jayaweera, M., Perera, H., Gunawardana, B., Manatunge, J., 2020. Transmission of COVID-19 virus by droplets and aerosols: A critical review on the unresolved dichotomy. Envronmental Res. 188, 1-18. https://doi.org/10.1016/j.envres.2020.109819

Ji, D., Fan, L., Li, X., Ramakrishna, S., 2020. Addressing the worldwide shortages of face masks. BMC Mater. 2, 1-11. https://doi.org/10.1186/s42833-020-00015-w

Jiang, C., Zhao, H., Xiao, H., Wang, Y., Liu, L., Chen, H., Shen, C., Zhu, H., Liu, Q., 2021. Recent advances in graphene-family nanomaterials for effective drug delivery and phototherapy. Expert Opin. Drug Deliv. 18, 119-138. https://doi.org/10.1080/17425247.2020.1798400

Jung, H., Kim, J., Lee, S., Lee, J., Kim, J., Tsai, P., Yoon, C., 2014. Comparison of filtration efficiency and pressure drop in anti-yellow sandmasks, quarantine masks, medical masks, general masks, and handkerchiefs. Aerosol Air Qual. Res. 14, 991-1002. https://doi.org/10.4209/aaqr.2013.06.0201

Jung, J.H., Cheon, D.S., Liu, F., Lee, K.B., Seo, T.S., 2010. A Graphene oxide based immuno- 
biosensor for pathogen detection. Angew. Chemie 122, 5844-5847. https://doi.org/10.1002/ange.201001428

Junter, G.A., Lebrun, L., 2017. Cellulose-based virus-retentive filters: a review. Rev. Environ. Sci. Biotechnol. 16, 455-489. https://doi.org/10.1007/s11157-017-9434-1

Karmacharya, M., Kumar, S., Gulenko, O., Cho, Y.K., 2021. Advances in facemasks during the COVID-19 pandemic era. ACS Appl. Bio Mater. 4, 3891-3908. https://doi.org/10.1021/acsabm.0c01329

Kasbe, P.S., Gade, H., Liu, S., Chase, G.G., Xu, W., 2021. Ultrathin polydopamine-graphene oxide hybrid coatings on polymer filters with improved filtration performance and functionalities. ACS Appl. Bio Mater. 4, 5180-5188. https://doi.org/10.1021/ACSABM.1C00367

Kilgannon, L., 2020. Haydale to distribute ppe face masks. https://www.insidermedia.com/news/wales/haydale-to-distribute-ppe-face-masks. (accessed 8 December 2020)

Konda, A., Prakash, A., Moss, G.A., Schmoldt, M., Grant, G.D., Guha, S., 2020. Aerosol filtration efficiency of common fabrics used in respiratory cloth masks. ACS Nano 14, 6339-6347. https://doi.org/10.1021/acsnano.0c03252

Krishnamoorthy, K., Veerapandian, M., Zhang, L., Yun, K., 2012. Antibacterial efficiency of graphene nanosheets against pathogenic bacteria via lipid peroxidation. J. Phys. Chem. C 116, 17280-17287. https://doi.org/https://doi.org/10.1021/jp3047054

Kucki, M., Diener, L., Bohmer, N., Hirsch, C., Krug, H.F., Palermo, V., Wick, P., 2017. Uptake of label-free graphene oxide by Caco-2 cells is dependent on the cell differentiation status. J. Nanobiotechnology 15, 1-18. https://doi.org/10.1186/s12951-017-0280-7

Kumar, P., Huo, P., Zhang, R., Liu, B., 2019. Antibacterial properties of graphene-based nanomaterials, Nanomat. 1-32. https://doi.org/doi:10.3390/nano9050737

Kumar, S., Chatterjee, K., 2016. Comprehensive review on the use of graphene-based substrates for regenerative medicine and biomedical devices. ACS Appl. Mater. Interfaces 8, 2643126457. https://doi.org/10.1021/acsami.6b09801

Lea, R., 2020. Graphene-Based Masks Launched to Combat COVID-19. https://www.azonano.com/news.aspx?newsID=37431. (assessed 9 July 2020)

Leung, N.H.L., Chu, D.K.W., Shiu, E.Y.C., Chan, K.H., McDevitt, J.J., Hau, B.J.P., Yen, H.L., Li, Y., Ip, D.K.M., Peiris, J.S.M., Seto, W.H., Leung, G.M., Milton, D.K., Cowling, B.J., 2020. Respiratory virus shedding in exhaled breath and efficacy of face masks. Nat. Med. 26, 676-680. https://doi.org/10.1038/s41591-020-0843-2

Li, J., Wang, G., Zhu, H., Zhang, M., Zheng, X., Di, Z., Liu, X., Wang, X., 2014. Antibacterial activity of large-area monolayer graphene film manipulated by charge transfer. Sci. Rep. 4. https://doi.org/10.1038/srep04359

Li, J., Zhang, D., Yang, T., Yang, S., Yang, X., Zhu, H., 2018. Nanofibrous membrane of graphene oxide-in-polyacrylonitrile composite with low filtration resistance for the effective capture of PM2.5. J. Memb. Sci. 551, 85-92. https://doi.org/10.1016/j.memsci.2018.01.025

Li, Q., Lu, J., Gupta, P., Qiu, M., 2019. Engineering optical absorption in graphene and other 2D materials: advances and applications. Adv. Opt. Mater. 7, 1-23. https://doi.org/10.1002/adom.201900595

Li, Y., Liu, Y., Fu, Y., Wei, T., Le Guyader, L., Gao, G., Liu, R.S., Chang, Y.Z., Chen, C., 2012. The triggering of apoptosis in macrophages by pristine graphene through the MAPK and TGF-beta signaling pathways. Biomaterials 33, 402-411. 
691

692

693

694

695

696

697

698

699

700

701

702

703

704

705

706

707

708

709

710

711

712

713

714

715

716

717

718

719

720

721

722

723

724

725

726

727

728

729

730

731

732

733

734

735

736

https://doi.org/10.1016/j.biomaterials.2011.09.091

Li, Y., Yuan, H., Von Dem Bussche, A., Creighton, M., Hurt, R.H., Kane, A.B., Gao, H., 2013. Graphene microsheets enter cells through spontaneous membrane penetration at edge asperities and corner sites. Proc. Natl. Acad. Sci. U. S. A. 110, 12295-12300. https://doi.org/10.1073/pnas.1222276110

Liao, K.H., Lin, Y.S., MacOsko, C.W., Haynes, C.L., 2011. Cytotoxicity of graphene oxide and graphene in human erythrocytes and skin fibroblasts. ACS Appl. Mater. Interfaces 3, 26072615. https://doi.org/10.1021/am200428v

Lin, Z., Wang, Z., Zhang, X., Diao, D., 2021. Superhydrophobic, photo-sterilize, and reusable mask based on graphene nanosheet-embedded carbon (GNEC) film. Nano Res. 14, 11101115. https://doi.org/10.1007/s12274-020-3158-1

Liu, F., Choi, K.S., Park, T.J., Lee, S.Y., Seo, T.S., 2011. Graphene-based electrochemical biosensor for pathogenic virus detection. Biochip J. 5, 123-128. https://doi.org/10.1007/s13206-011-5204-2

Liu, G., Jin, W., Xu, N., 2015. Graphene-based membranes. Chem Soc Rev 5016-5030. https://doi.org/10.1039/c4cs00423j

Liu, S., Zeng, T.H., Hofmann, M., Burcombe, E., Wei, J., Jiang, R., Kong, J., Chen, Y., 2011. Antibacterial activity of graphite, graphite oxide, graphene oxide, and reduced graphene oxide: membrane and oxidative stress. ACS Nano 5, 6971-6980. https://doi.org/10.1021/nn202451x

Long, Y., Hu, T., Liu, L., Chen, R., Guo, Q., Yang, L., Cheng, Y., Huang, J., Du, L., 2020. Effectiveness of N95 respirators versus surgical masks against influenza: A systematic review and meta-analysis. J. Evid. Based. Med. 13, 93-101. https://doi.org/10.1111/jebm.12381

Lu, J., Zhu, X., Tian, S., Lv, X., Chen, Z., Jiang, Y., Liao, X., Cai, Z., Chen, B., 2018. Graphene oxide in the marine environment: Toxicity to Artemia salina with and without the presence of Phe and Cd2+. Chemosphere 211, 390-396. https://doi.org/10.1016/j.chemosphere.2018.07.140

Ma-Hock, L., Strauss, V., Treumann, S., Küttler, K., Wohlleben, W., Hofmann, T., Gröters, S., Wiench, K., van Ravenzwaay, B., Landsiedel, R., 2013. Comparative inhalation toxicity of multi-wall carbon nanotubes, graphene, graphite nanoplatelets and low surface carbon black. Part. Fibre Toxicol. 10. https://doi.org/10.1186/1743-8977-10-23

Majeed, W., Bourdo, S., Petibone, D.M., Saini, V., Vang, K.B., Nima, Z.A., Alghazali, K.M., Darrigues, E., Ghosh, A., Watanabe, F., Casciano, D., Ali, S.F., Biris, A.S., 2017. The role of surface chemistry in the cytotoxicity profile of graphene. J. Appl. Toxicol. 37, 462-470. https://doi.org/10.1002/jat.3379

Maqbool, I., Rehman, F., Soomro, F., Bhatti, Z., Ali, U., Jatoi, A.H., Lal, B., Iqbal, M., Phulpoto, S., Ali, A., Thebo, K.H., 2021. Graphene-based materials for fighting coronavirus disease 2019: challenges and opportunities. ChemBioEng Rev. 8, 67-77. https://doi.org/10.1002/cben.202000039

Matharu, R.K., Porwal, H., Chen, B., Ciric, L., Edirisinghe, M., 2020. Viral filtration using carbon-based materials. Med. Devices Sensors 3, 1-7. https://doi.org/10.1002/mds3.10107

Matuschek, C., Moll, F., Fangerau, H., Fischer, J.C., Zänker, K., Van Griensven, M., Schneider, M., Kindgen-Milles, D., Knoefel, W.T., Lichtenberg, A., Tamaskovics, B., DjiepmoNjanang, F.J., Budach, W., Corradini, S., Häussinger, D., Feldt, T., Jensen, B., Pelka, R., Orth, K., Peiper, M., Grebe, O., Maas, K., Gerber, P.A., Pedoto, A., Bölke, E., Haussmann, 
J., 2020. Face masks: Benefits and risks during the COVID-19 crisis. Eur. J. Med. Res. 25, 1-8. https://doi.org/10.1186/s40001-020-00430-5

Missoni, E., Armocida, B., Formenti, B., 2021. Face masks for all and all for face masks in the COVID-19 pandemic: community level production to face the global shortage and shorten the epidemic. Disaster Med. Public Health Prep. 15, e29-e33. https://doi.org/10.1017/dmp.2020.207

Mojsoska, B., Larsen, S., Olsen, D.A., Madsen, J.S., Brandslund, I., Alatraktchi, F.A., 2021. Rapid SARS-CoV-2 detection using electrochemical immunosensor. Sensors 21, 1-11. https://doi.org/10.3390/s21020390

Moore, S., 2021. World-first graphene membrane face mask that kills COVID-19. https://www.azonano.com/article.aspx?ArticleID=5754. (assessed 7 July 2021)

Morawska, L., Tang, J.W., Bahnfleth, W., Bluyssen, P.M., Boerstra, A., Buonanno, G., Cao, J., Dancer, S., Floto, A., Franchimon, F., Haworth, C., Hogeling, J., Isaxon, C., Jimenez, J.L., Kurnitski, J., Li, Y., Loomans, M., Marks, G., Marr, L.C., Mazzarella, L., Melikov, A.K., Miller, S., Milton, D.K., Nazaroff, W., Nielsen, P. V., Noakes, C., Peccia, J., Querol, X., Sekhar, C., Seppänen, O., Tanabe, S. ichi, Tellier, R., Tham, K.W., Wargocki, P., Wierzbicka, A., Yao, M., 2020. How can airborne transmission of COVID-19 indoors be minimised? Environ. Int. 142. https://doi.org/10.1016/j.envint.2020.105832

Mukherjee, S.P., Kostarelos, K., Fadeel, B., 2018. Cytokine profiling of primary human macrophages exposed to endotoxin-free graphene oxide: size-independent NLRP3 inflammasome activation. Adv. Healthc. Mater. 7, 1-14. https://doi.org/10.1002/adhm.201700815

Musico, Y.L.F., Santos, C.M., Dalida, M.L.P., Rodrigues, D.F., 2014. Surface modification of membrane filters using graphene and graphene oxide-based nanomaterials for bacterial inactivation and removal. ACS Sustain. Chem. Eng. 2, 1559-1565. https://doi.org/10.1021/sc500044p

Nacinopa, G., 2020. The power of graphene : product \& market versatility with flextrapower. https://blog.brinc.io/the-power-of-graphene-product-market-versatility-with-flextrapowere9604a94019a. (assessed 16 September 2020)

Nasirzadeh, N., Azari, M.R., Rasoulzadeh, Y., Mohammadian, Y., 2019. An assessment of the cytotoxic effects of graphene nanoparticles on the epithelial cells of the human lung. Toxicol. Ind. Health 35, 79-87. https://doi.org/10.1177/0748233718817180

Nguyen, H.N., Chaves-Lopez, C., Oliveira, R.C., Paparella, A., Rodrigues, D.F., 2019. Cellular and metabolic approaches to investigate the effects of graphene and graphene oxide in the fungi Aspergillus flavus and Aspergillus niger. Carbon N. Y. 143, 419-429. https://doi.org/10.1016/j.carbon.2018.10.099

Ogbuoji, E.A., Zaky, A.M., Escobar, I.C., 2021. Advanced research and development of face masks and respirators pre and post the coronavirus disease 2019 (Covid-19) pandemic: A critical review. Polymers (Basel). 13. https://doi.org/10.3390/polym13121998

Orecchioni, M., Bedognetti, D., Newman, L., Fuoco, C., Spada, F., Hendrickx, W., Marincola, F.M., Sgarrella, F., Rodrigues, A.F., Ménard-Moyon, C., Cesareni, G., Kostarelos, K., Bianco, A., G Delogu, L., 2017. Single-cell mass cytometry and transcriptome profiling reveal the impact of graphene on human immune cells. Nat. Commun. 8. https://doi.org/10.1038/s41467-017-01015-3

Pal, K., Kyzas, G.Z., Kralj, S., Gomes de Souza, F., 2021. Sunlight sterilized, recyclable and super hydrophobic anti-COVID laser-induced graphene mask formulation for indelible 
801

802

803

804

805

806

807

808

809

810

811

812

813

814

815

816

817

818

819

820

821

822

823

824

825

826

827

828

usability. J. Mol. Struct. 1233, 130100. https://doi.org/10.1016/j.molstruc.2021.130100

Palmieri, V., Papi, M., 2020. Can graphene take part in the fight against COVID-19? Nano Today 33, 100883. https://doi.org/10.1016/j.nantod.2020.100883

Park, C.-Y., Kim, K., Roth, S., Beck, S., Kang, J.W., Tayag, M.C., Griffin, M., 2019. Global shortage of personal protective equipment amid COVID-19: supply chains, bottlenecks, and $\begin{array}{lllll}\text { policy implications. } & \text { ADB } & \text { briefs } & 108, & 1-8 \text {. }\end{array}$ https://doi.org/http://dx.doi.org/10.22617/BRF200128-2 Global

Parlin, A.F., Stratton, S.M., Culley, T.M., Guerra, P.A., 2020. A laboratory-based study examining the properties of silk fabric to evaluate its potential as a protective barrier for personal protective equipment and as a functional material for face coverings during the COVID-19 pandemic. PLoS One 15, 1-19. https://doi.org/10.1371/journal.pone.0239531

Payandehpeyman, J., Parvini, N., Moradi, K., Hashemian, N., 2021. Detection of SARS-CoV-2 using antibody-antigen interactions with graphene-based nanomechanical resonator sensors. ACS Appl. Nano Mater. 4, 6189-6200. https://doi.org/10.1021/acsanm.1c00983

Perini, G., Palmieri, V., Ciasca, G., D’Ascenzo, M., Primiano, A., Gervasoni, J., De Maio, F., De Spirito, M., Papi, M., 2020. Enhanced chemotherapy for glioblastoma quantum dots. Materials (Basel). 13, 4139.

Perreault, F., De Faria, A.F., Nejati, S., Elimelech, M., 2015. Antimicrobial properties of graphene oxide nanosheets: why size matters. ACS Nano 9, 7226-7236. https://doi.org/10.1021/acsnano.5b02067

Pinals, R.L., Ledesma, F., Yang, D., Navarro, N., Jeong, S., Pak, J.E., Kuo, L., Chuang, Y.C., Cheng, Y.W., Sun, H.Y., Landry, M.P., 2021. Rapid SARS-CoV-2 spike protein detection by carbon nanotube-based near-infrared nanosensors. medRxiv 21, 2272-2280. https://doi.org/10.1021/acs.nanolett.1c00118

Pranno, N., Monaca, G. La, Polimeni, A., Sarto, M.S., Uccelletti, D., Bruni, E., Cristalli, M.P., Cavallini, D., Vozza, I., 2020. Antibacterial activity against staphylococcus aureus of titanium surfaces coated with graphene nanoplatelets to prevent peri-implant diseases. An in-vitro pilot study. Int. J. Environ. Res. Public Health 17. https://doi.org/10.3390/ijerph17051568

Pu, Y., Zheng, J., Chen, F., Long, Y., Wu, H., Li, Q., Yu, S., Wang, X., Ning, X., 2018. Preparation of polypropylene micro and nanofibers by electrostatic-assisted melt blown and their application. Polymers (Basel). 10, 1-12. https://doi.org/10.3390/polym10090959

Pullangott, G., Kannan, U., S., G., Kiran, D.V., Maliyekkal, S.M., 2021. A comprehensive review on antimicrobial face masks: an emerging weapon in fighting pandemics. RSC Adv. 11, 6544-6576. https://doi.org/10.1039/d0ra10009a

Rajakumari, R., Tharayil, A., Thomas, S., Kalarikkal, N., 2020. Toxicity of graphene based nanomaterials - a general overview of origin, exposure and mechanisms, in: Comprehensive Analytical Chemistry. Elsevier B.V., pp. 281-325. https://doi.org/10.1016/bs.coac.2020.09.004

Ramal-Sanchez, M., Fontana, A., Valbonetti, L., Ordinelli, A., Bernabò, N., Barboni, B., 2021. Graphene and reproduction: a love-hate relationship. Nanomaterials 11, 1-16. https://doi.org/10.3390/nano11020547

Ramírez-Guerrero, J.A., 2021. The importance of nonmedical face masks in the general population during the COVID-19 pandemic. a narrative review. Rev. Mex. Anestesiol. 44, 130-138. https://doi.org/10.35366/99017

Raval, B., Srivastav, A.K., Gupta, S.K., Kumar, U., Mahapatra, S.K., Gajjar, P.N., Banerjee, I., 
2020. Synthesis of exfoliated multilayer graphene and its putative interactions with SARSCoV-2 virus investigated through computational studies. J. Biomol. Struct. Dyn. 0, 1-10. https://doi.org/10.1080/07391102.2020.1817788

Ray, S.S., Bandyopadhyay, J., 2021. Nanotechnology-enabled biomedical engineering: Current trends, future scopes, and perspectives. Nanotechnol. Rev. 10, 728-743. https://doi.org/10.1515/ntrev-2021-0052

Reina, G., Iglesias, D., Samorì, P., Bianco, A., 2021. Graphene: a disruptive opportunity for COVID-19 and future pandemics? Adv. Mater. 33, 1-10. https://doi.org/10.1002/adma.202007847

Rengasamy, S., Zhuang, Z., Niezgoda, G., Walbert, G., Lawrence, R., Boutin, B., Hudnall, J., Monaghan, W.P., Bergman, M., Miller, C., Harris, J., Coffey, C., 2018. A comparison of total inward leakage measured using sodium chloride $(\mathrm{NaCl})$ and corn oil aerosol methods for air-purifying respirators. J. Occup. Environ. Hyg. 15, 616-627. https://doi.org/10.1080/15459624.2018.1479064

Rhazouani, A., Aziz, K., Gamrani, H., Gebrati, L., Uddin, S., 2020. Can the application of graphene oxide contribute to the fight against COVID-19? Antiviral activity, diagnosis and prevention. Curr. Res. Pharmacol. Drug Discov. 2. https://doi.org/https://doi.org/10.1016/j.crphar.2021.100062

Saleh, T.A., Fadillah, G., 2019. Recent trends in the design of chemical sensors based on graphene-metal oxide nanocomposites for the analysis of toxic species and biomolecules. Trends Anal. Chem. 120, 115660. https://doi.org/10.1016/j.trac.2019.115660

Salter, S., 2021. Reinventing cloth masks in the face of pandemics. Risk Anal. 41, 731-744. https://doi.org/10.1111/risa.13602

Sandle, T., 2021. Graphene based face mask uses novel technology to inhibit viruses ( Includes first-hand account ).

Santos, M., Torres, D., Cardoso, P.C., Pandis, N., Flores-Mir, C., Medeiros, R., Normando, A.D., 2020. Are cloth masks a substitute to medical masks in reducing transmission and contamination? A systematic review. Braz. Oral Res. 34, 1-17. https://doi.org/10.1590/1807-3107bor-2020.vol34.0123

Sasidharan, A., Panchakarla, L.S., Sadanandan, A.R., Ashokan, A., Chandran, P., Girish, C.M., Menon, D., Nair, S. V., Rao, C.N.R., Koyakutty, M., 2012. Hemocompatibility and macrophage response of pristine and functionalized graphene. Small 8, 1251-1263. https://doi.org/10.1002/smll.201102393

Schinwald, A., Murphy, F. a, Jones, A., Macnee, W., Donaldson, K., 2012. Graphene-based nanoplatelets: a new risk to the respiratory system. ACS Nano 736-746.

Seifi, T., Reza Kamali, A., 2021. Antiviral performance of graphene-based materials with emphasis on COVID-19: A review. Med. Drug Discov. 11. https://doi.org/10.1016/j.medidd.2021.100099

Seo, G., Lee, G., Kim, M.J., Baek, S.H., Choi, M., Ku, K.B., Lee, C.S., Jun, S., Park, D., Kim, H.G., Kim, S.J., Lee, J.O., Kim, B.T., Park, E.C., Kim, S. Il, 2020. Rapid detection of COVID-19 causative virus (SARS-CoV-2) in human nasopharyngeal swab specimens using field-effect transistor-based biosensor. ACS Nano 14, 5135-5142. https://doi.org/10.1021/acsnano.0c02823

Shaikh, I., 2021. Impact of COVID-19 pandemic disease outbreak on the global equity markets. Econ. Res. Istraz. 34, 2317-2336. https://doi.org/10.1080/1331677X.2020.1863245

Shan, X., Zhang, H., Liu, C., Yu, L., Di, Y., Zhang, X., Dong, L., Gan, Z., 2020. Reusable self- 
sterilization masks based on electrothermal graphene filters. ACS Appl. Mater. Interfaces 12, 56579-56586. https://doi.org/10.1021/acsami.0c16754

Shanmugam, V., Babu, K., Garrison, T.F., Capezza, A.J., Olsson, R.T., Ramakrishna, S., Hedenqvist, M.S., Singha, S., Bartoli, M., Giorcelli, M., Sas, G., Försth, M., Das, O., Restás, Á., Berto, F., 2021. Potential natural polymer-based nanofibres for the development of facemasks in countering viral outbreaks. J. Appl. Polym. Sci. 138, 1-19. https://doi.org/10.1002/app.50658

Sharma, S., Mishra, M., Mudgal, S., 2020. Efficacy of cloth face mask in prevention of novel coronavirus infection transmission: A systematic review and meta-analysis. J. Educ. Health Promot. 9. https://doi.org/10.4103/JEHP.JEHP_533_20

Shin, J.H., Han, S.G., Kim, J.K., Kim, B.W., Hwang, J.H., Lee, J.S., Lee, J.H., Baek, J.E., Kim, T.G., Kim, K.S., Lee, H.S., Song, N.W., Ahn, K., Yu, I.J., 2015. 5-Day repeated inhalation and 28-day post-exposure study of graphene. Nanotoxicology 9, 1023-1031. https://doi.org/10.3109/17435390.2014.998306

Song, Z., Wang, X., Zhu, G., Nian, Q., Zhou, H., Yang, D., Qin, C., Tang, R., 2015. Virus capture and destruction by label-free graphene oxide for detection and disinfection applications. Small 11, 1771-1776. https://doi.org/10.1002/smll.201401706

Stanford, M.G., Li, J.T., Chen, Y., Mchugh, E.A., Liopo, A., Xiao, H., Tour, J.M., 2019. Selfsterilizing laser-induced graphene bacterial air filter. ACS Nano 13, 11912-11920. https://doi.org/10.1021/acsnano.9b05983

Stutt, R.O.J.H., Retkute, R., Bradley, M., Gilligan, C.A., Colvin, J., 2020. A modelling framework to assess the likely effectiveness of facemasks in combination with 'lock-down' in managing the covid-19 pandemic. Proc. R. Soc. A 476. https://doi.org/10.1098/rspa.2020.0376

Tabish, T.A., Pranjol, M.Z.I., Jabeen, F., Abdullah, T., Latif, A., Khalid, A., Ali, M., Hayat, H., Winyard, P.G., Whatmore, J.L., Zhang, S., 2018. Investigation into the toxic effects of graphene nanopores on lung cancer cells and biological tissues. Appl. Mater. Today 12, 389-401. https://doi.org/10.1016/j.apmt.2018.07.005

Tcharkhtchi, A., Abbasnezhad, N., Zarbini Seydani, M., Zirak, N., Farzaneh, S., Shirinbayan, M., 2021. An overview of filtration efficiency through the masks: mechanisms of the aerosols penetration. Bioact. Mater. 106-122. https://doi.org/10.1016/j.bioactmat.2020.08.002

Thebo, K.H., Qian, X., Zhang, Q., Chen, L., Cheng, H.M., Ren, W., 2018. Highly stable graphene-oxide-based membranes with superior permeability. Nat. Commun. 9, 1-8. https://doi.org/10.1038/s41467-018-03919-0

Tirupathi, R., Bharathidasan, K., Palabindala, V., Salim, S.A., Al-Tawfiq, J.A., 2020. Comprehensive review of mask utility and challenges during the COVID-19 pandemic. Le Infez. Med. 28, 57-63.

Torrente-Rodríguez, R.M., Lukas, H., Tu, J., Min, J., Yang, Y., Xu, C., Rossiter, H.B., Gao, W., 2020. SARS-CoV-2 Rapidplex: a graphene-based multiplexed telemedicine platform for rapid and low-cost COVID-19 diagnosis and monitoring. Matter 3, 1981-1998. https://doi.org/10.1016/j.matt.2020.09.027

Trache, D., Tarchoun, A.F., Derradji, M., Hamidon, T.S., Masruchin, N., Brosse, N., Hussin, M.H., 2020. Nanocellulose: from fundamentals to advanced applications, Frontiers in Chemistry. https://doi.org/10.3389/fchem.2020.00392

Varma, P., Junge, M., Meaklim, H., Jackson, M.L., 2021. Younger people are more vulnerable to 
stress, anxiety and depression during COVID-19 pandemic: A global cross-sectional survey.

$\begin{array}{lllll}\text { Prog. Neuro-Psychopharmacology Biol. } \quad \text { Psychiatry } & 109, \quad 10236 .\end{array}$ https://doi.org/10.1016/j.pnpbp.2020.110236

Wang, L., Davidson, D.C., Castranova, V., Rojanasakul, Y., 2016. Pulmonary effects of carbon nanomaterials, in: Biomedical Applications and Toxicology of Carbon Nanomaterials. Wiley-VCH Verlag GmbH \& Co. KGaA, pp. 163-193. https://doi.org/10.1002/9783527692866.ch6

Wang, R., Guan, S., Sato, A., Wang, X., Wang, Z., Yang, R., Hsiao, B.S., Chu, B., 2013. Nanofibrous microfiltration membranes capable of removing bacteria, viruses and heavy metal ions. J. Memb. Sci. 446, 376-382. https://doi.org/10.1016/j.memsci.2013.06.020

World Health Organization. 2020. Mask use in the context of COVID-19: interim guidance. https://apps.who.int/iris/handle/10665/337199. (assessed 1 December 2020)

Worby, C.J., Chang, H.H., 2020. Face mask use in the general population and optimal resource allocation during the COVID-19 pandemic. Nat. Commun. 11, 1-9. https://doi.org/10.1038/s41467-020-17922-X

Xu, Y., Lu, Y., Li, J., Liu, R., Zhu, X., 2020. Effect of graphene quantum dot size on plant growth. Nanoscale 12, 15045-15049. https://doi.org/10.1039/d0nr01913e

Yan, Y., Bayham, J., Richter, A., Fenichel, E.P., 2021. Risk compensation and face mask mandates during the COVID-19 pandemic. Sci. Rep. 11, 1-11. https://doi.org/10.1038/s41598-021-82574-w

Yan, Y., Shin, W.I., Chen, H., Lee, S.M., Manickam, S., Hanson, S., Zhao, H., Lester, E., Wu, T., Pang, C.H., 2021. A recent trend: application of graphene in catalysis. Carbon Lett. 31, 177-199. https://doi.org/10.1007/s42823-020-00200-7

Yang, P., Wang, X., 2020. COVID-19: a new challenge for human beings. Cell. Mol. Immunol. 17, 555-557. https://doi.org/10.1038/s41423-020-0407-X

Yang, X.X., Li, C.M., Li, Y.F., Wang, J., Huang, C.Z., 2017. Synergistic antiviral effect of curcumin functionalized graphene oxide against respiratory syncytial virus infection. Nanoscale 9, 16086-16092. https://doi.org/10.1039/c7nr06520e

Zhang, M., Gao, B., Chen, J., Li, Y., 2015. Effects of graphene on seed germination and seedling growth. J. Nanoparticle Res. 17. https://doi.org/10.1007/s11051-015-2885-9

Zhang, T., Tremblay, P.L., 2020. Graphene: an antibacterial agent or a promoter of bacterial proliferation? iScience 23, 101787. https://doi.org/10.1016/j.isci.2020.101787

Zhang, X., Cao, H., Wang, H., Zhang, R., Jia, H., Huang, J., Zhao, J., Yao, J., 2021. Effects of graphene on morphology, microstructure and transcriptomic profiling of Pinus tabuliformis Carr. roots. PLoS One 16, 1-17. https://doi.org/10.1371/journal.pone.0253812

Zhang, Y., Ali, S.F., Dervishi, E., Xu, Y., Li, Z., Casciano, D., Biris, A.S., 2010. Cytotoxicity effects of graphene and single-wall carbon nanotubes in neural phaeochromocytomaderived pc12 cells. ACS Nano 4, 3181-3186. https://doi.org/10.1021/nn1007176

Zhang, Z., Ji, D., He, H., Ramakrishna, S., 2020. Electrospun ultrafine fibers for advanced face masks Zhenfang. https://doi.org/doi: 10.1016/j.mser.2020.100594

Zhao, J., Deng, B., Lv, M., Li, J., Zhang, Y., Jiang, H., Peng, C., Li, J., Shi, J., Huang, Q., Fan, C., 2013. Graphene oxide-based antibacterial cotton fabrics. Adv. Healthc. Mater. 2, 12591266. https://doi.org/10.1002/ADHM.201200437

Zhong, H., Zhu, Z., Lin, J., Cheung, C.F., Lu, V.L., Yan, F., Chan, C.Y., Li, G., 2020. Reusable and recyclable graphene masks with outstanding superhydrophobic and photothermal performances. ACS Nano 14, 6213-6221. https://doi.org/10.1021/acsnano.0c02250

Peer) Mat. Sci. reviewing PDF | (MATSCI-2021:10:66874:1:1:NEW 15 Jan 2022) 
967 Zhou, H., Zhao, K., Li, W., Yang, N., Liu, Y., Chen, C., Wei, T., 2012. The interactions between 968 pristine graphene and macrophages and the production of cytokines/chemokines via TLR969 and NF-кB-related signaling pathways. Biomaterials 33, 6933-6942. $970 \quad$ https://doi.org/10.1016/j.biomaterials.2012.06.064

971 Zhou, R., Gao, H., 2014. Cytotoxicity of graphene: recent advances and future perspective. 972 WIREs Nanomed Nanobiotechnol 6, 452-474. https://doi.org/10.1002/wnan.1277

973 Zou, X., Zhang, L., Wang, Z., Luo, Y., 2016. Mechanisms of the antimicrobial activities of 974 graphene materials. J. Am. Chem. Soc. 138, 2064-2077.

$975 \quad$ https://doi.org/10.1021/jacs.5b11411 


\section{Table $\mathbf{1}$ (on next page)}

features of different types of graphene face masks 
1 Table 1 features of different types of graphene face masks

\begin{tabular}{|c|c|c|c|}
\hline S.N. & $\begin{array}{l}\text { List of grapheme } \\
\text { facemask }\end{array}$ & Features & Ref. \\
\hline 1. & $\begin{array}{l}\text { Graphene nano } \\
\text { sheet-embedded } \\
\text { carbon } \quad(\text { GNEC) } \\
\text { facemask }\end{array}$ & $\begin{array}{l}\text { The mask has an excellent hydrophobic property, incredible bacterial } \\
\text { filtering efficiency, and prominent photo-sterilized performance. Masks } \\
\text { have great potential to work against the spread of the COVID-19 } \\
\text { pandemic. }\end{array}$ & $\begin{array}{l}\text { (Lin et al., } \\
2021)\end{array}$ \\
\hline 2. & $\begin{array}{l}\text { Graphene mounted } \\
\text { 3D printed facial } \\
\text { mask }\end{array}$ & $\begin{array}{l}\text { The bacterial filtration efficiency of the mask is } 98.2 \% \text { and the } \\
\text { breathing resistance is } 1.10 \text { mbar. Transmission of the SARS-CoV- } 2 \\
\text { virus through graphene filters was not reported. }\end{array}$ & $\begin{array}{l}\text { (Goswami et } \\
\text { al., 2021) }\end{array}$ \\
\hline 3. & $\begin{array}{l}\text { Flextrapower } \\
\text { graphene mask }\end{array}$ & $\begin{array}{l}\text { The mask is carefully made and is safe to wear. The mask follows } \\
\text { unique and sophisticated hydrophobic nanotechnology in which virus } \\
\text { aerosolized droplets are unable to remain on the exposed layer for long } \\
\text { periods. }\end{array}$ & $\begin{array}{l}\text { (Nacinopa, } \\
2020)\end{array}$ \\
\hline 4. & $\begin{array}{l}\text { Laser-Induced } \\
\text { graphene mask }\end{array}$ & $\begin{array}{l}\text { Most of the bacteria remain alive even after the mask is exposed to } \\
\text { sunlight for } 8 \text { hours. The mask has shown superior antibacterial action } \\
\text { and can be enhanced by photothermal energy. }\end{array}$ & $\begin{array}{l}\text { (Huang et al., } \\
2020 \text { ) }\end{array}$ \\
\hline 5. & Endothermal mask & $\begin{array}{l}\text { It is very easy to raise the temperature of the face mask above } 80^{\circ} \mathrm{C} \text { by } \\
\text { supplying } 3 \mathrm{~V} \text { of energy. The mask filters the air at this temperature by } \\
\text { killing all known types of bacteria and viruses. It preserves high } \\
\text { particulate matter efficiency and is reusable. }\end{array}$ & $\begin{array}{l}\text { (Shan et al., } \\
2020)\end{array}$ \\
\hline 6. & $\begin{array}{l}\text { Graphene oxide- } \\
\text { based rechargeable } \\
\text { respiratory mask }\end{array}$ & $\begin{array}{l}\text { The mask comes at a very low price }(\sim \$ 1 / \text { mask }) \text {. Its rechargeability and } \\
\text { filtering efficiency of more than } 95 \% \text {. The electrostatic charge retention } \\
\text { capacity is very high }(\sim 1 \mathrm{nC} / \mathrm{cm} 2) \text {. Even in high humid conditions, the } \\
\text { mask recharges very quickly. }\end{array}$ & $\begin{array}{l}\text { (Figerez et al., } \\
2020)\end{array}$ \\
\hline 7. & $\mathrm{G}+$ masks & $\begin{array}{l}\text { The G+ mask has been certified to the European standard EN } 14683 \text { as } \\
\text { an excellent air filtering biocompatible device. It is naturally } \\
\text { bacteriostatic and hypoallergenic. The ability to filter while breathing } \\
\text { with this mask is very high. It is reusable, washable and the filtering } \\
\text { membrane is replaceable. }\end{array}$ & $\begin{array}{l}\text { (Bhattacharjee } \\
\text { et al., 2019) }\end{array}$ \\
\hline 8. & G1 wonder mask & $\begin{array}{l}\text { Graphene-silver nanomaterials are used to design the filtering } \\
\text { membrane. This increases the filtering efficiency of the G1 Wonder } \\
\text { Mask. The mask is reusable, washable, breathable, and eco-friendly. It } \\
\text { can kill } 99 \% \text { of bacteria and viruses in just one second, and also prevent } \\
\text { the volatile organic compound from entering inside respiratory organs. }\end{array}$ & $\begin{array}{l}\text { (Moore, } \\
2021)\end{array}$ \\
\hline 9. & Graphene masks & $\begin{array}{l}\text { The mask is super-hydrophobic due to the embedded graphene } \\
\text { nanoparticles. Exposure to sunlight can raise its temperature to } 80^{\circ} \mathrm{C} \\
\text { which is enough to kill bacteria and viruses. In this mask, monolayered } \\
\text { nanographene particles are deposited on a non-woven surface at low } \\
\text { melting temperatures by a laser-induced forward transfer method. }\end{array}$ & $\begin{array}{l}\text { (Zhong et al., } \\
2020 \text { ) }\end{array}$ \\
\hline 10. & $\begin{array}{l}2 \text { AM graphene } \\
\text { enhanced facemask }\end{array}$ & $\begin{array}{l}\text { This type of face mask consists of three-layered materials such as } \\
\text { graphene (outer layer), polyester (middle layer), and } 100 \% \text { cotton } \\
\text { (inner layer). Graphene material is anti-static, dust repellent, and filters } \\
\text { out PM2.5 airborne particulates. It is washable and also bacteria } \\
\text { resistant. The even distribution of heat energy from graphene provides } \\
\text { additional comfort to the users of this mask. }\end{array}$ & $\begin{array}{l}\text { (Maqbool et } \\
\text { al., 2021) }\end{array}$ \\
\hline 11. & Graphene facemask & $\begin{array}{l}\text { This is an antibacterial face mask, and the antibacterial properties } \\
\text { remain the same even after washing the mask } 10 \text { times. It comes in a } \\
\text { variety of shapes and sizes, and the mask is flexible as well. In addition, } \\
\text { users will feel comfortable while breathing in hot or cold weather. }\end{array}$ & $\begin{array}{l}\text { (Kilgannon, } \\
2020)\end{array}$ \\
\hline 12. & $\begin{array}{l}\text { Medieval facemask } \\
\text { with graphene }\end{array}$ & $\begin{array}{l}\text { The mask is comfortable, durable, and wearable without fogging } \\
\text { glasses. Antibacterial and hypoallergenic ingredients have been used in } \\
\text { this mask. From the inner side, the organic lining has been retained for } \\
\text { soft and comfortable wear. }\end{array}$ & $\begin{array}{l}\text { (Sandle, } \\
\text { 2021) }\end{array}$ \\
\hline 13. & $\begin{array}{l}\text { Guardian } \\
\text { masks }\end{array}$ & $\begin{array}{l}\text { The mask is rechargeable and can be sterilized and reusable. It shows } \\
\text { antimicrobial properties and repels the microorganism by attachment to }\end{array}$ & $\begin{array}{l}\text { (Pullangott et } \\
\text { al., 2021) }\end{array}$ \\
\hline
\end{tabular}


the exposed surface of the face mask.

14. $\mathrm{G} / \mathrm{GO}-$ functionalized polyurethane cotton facemask

15. Anti-COVID laserinduced graphene mask
The G/GO nanoparticles functionalized cotton face mask has (De Maio et significantly enhanced protection against the SARS-CoV-2 virus. It has al., 2021)

or shown antibacterial properties when the material was tested against $\mathrm{E}$. coli.

The mask has superhydrophobic and reusable properties. Sunlight (Pal et al., empowers the sterilization of facemask. Exposure of a mask to sunlight 2021) can increase its temperature by more than $80^{\circ} \mathrm{C}$.

2 


\section{Table 2 (on next page)}

Toxicity of graphene nanomaterial at a cellular level 
1 Table 2 Toxicity of graphene nanomaterial at a cellular level

\begin{tabular}{|c|c|c|c|c|c|c|c|c|}
\hline Nanoparticle & $\xi$ pot & Size of Nanoparticle & Cells & $\begin{array}{l}\text { Dose }(\mu \mathrm{g} / \mathrm{ml}, \\
\mu \mathrm{g} / \mathrm{Kg})\end{array}$ & $\begin{array}{l}\text { Time after } \\
\text { administration } \\
\text { /Incubation }\end{array}$ & $\begin{array}{l}\text { Toxicity } \\
\text { assessment }\end{array}$ & Result/effect & Ref. \\
\hline $\begin{array}{l}\text { Pristine } \\
\text { graphene } \\
\text { (PG) }\end{array}$ & $-6.12 \mathrm{mV}$ & $\begin{array}{l}\text { Surface diameter } \\
\text { ranges from } 350 \mathrm{~nm} \\
\text { to } 6 \mu \mathrm{m}\end{array}$ & $\begin{array}{l}\text { HS-5 r cells } \\
\text { (bone marrow/ } \\
\text { stroma) }\end{array}$ & $(5-100) \mu \mathrm{g} / \mathrm{ml}$. & $24 \mathrm{~h}$ & $\begin{array}{l}\text { The metabolic } \\
\text { rate of HS-5 } \\
\text { cells and } \\
\text { Intracellular } \\
\text { ROS level. }\end{array}$ & $\begin{array}{l}\text { The result showed high interaction of } \\
\text { cells with pristine graphene and very fast } \\
\text { agglomeration of PG nanoparticles on the } \\
\text { cell surface. The viability of cells began } \\
\text { to decline after } 20-100 \mu \mathrm{g} / \mathrm{mL} \text {. } \\
\text { Additionally, the level of ROS was } \\
\text { increased to } 20 \mu \mathrm{g} / \mathrm{mL} \text { at the higher } \\
\text { concentration of PG. }\end{array}$ & $\begin{array}{l}\text { (Jaworski et al. } \\
2021 \text { ) }\end{array}$ \\
\hline $\begin{array}{l}\text { Graphene } \\
\text { Nanoparticles } \\
\text { (GNPs) }\end{array}$ & $\begin{array}{l}\text { No } \\
\text { information }\end{array}$ & No information & $\begin{array}{l}\text { Lung cancer } \\
\text { cells (SKMES- } \\
\text { 1, A549). }\end{array}$ & $\begin{array}{lr}(5, & 50, \\
500, & 250 \\
\mu \mathrm{g} / \mathrm{ml} & 1000)\end{array}$ & $24 \mathrm{~h}$ & $\begin{array}{l}\text { Toxicity of } \\
\text { graphene } \\
\text { nanopores on } \\
\text { lung cancer } \\
\text { cells. }\end{array}$ & $\begin{array}{l}\text { The toxicity of graphene was } \\
\text { concentration-dependent. This resulted in } \\
\text { late apoptosis at a concentration of }>250 \\
\text { g/ml. At low concentrations, GNP does } \\
\text { not significantly cleave the cell } \\
\text { membrane. }\end{array}$ & $\begin{array}{l}\text { (Tabish et al., } \\
\text { 2018) }\end{array}$ \\
\hline $\begin{array}{l}\text { Graphene } \\
\text { Sheet (GS) }\end{array}$ & $\begin{array}{l}-37.2 \pm \quad 1.6 \\
\mathrm{mV}\end{array}$ & $\begin{array}{l}\text { Hydrodynamic } \\
\text { diameter } 3018 \pm 36 \\
\text { nm in D.I. water }\end{array}$ & $\begin{array}{lr}\text { Human } & \text { Red } \\
\text { Blood } & \text { Cells } \\
(\text { RBC), } & \text { Human } \\
\text { Skin } & \text { Fibroblast } \\
\text { cells } & \text { (CRL- } \\
2522) & \end{array}$ & $\begin{array}{l}(3.125-200) \\
\mu \mathrm{g} / \mathrm{ml}\end{array}$ & $24 \mathrm{~h}$ & $\begin{array}{l}\text { ROS } \\
\text { generation, } \\
\text { hemolytic } \\
\text { effect on RBC, } \\
\text { apoptosis of } \\
\text { viable cells. }\end{array}$ & $\begin{array}{l}\text { The surface charge of GS is responsible } \\
\text { for the hemolytic activity of erythrocytes } \\
\text { and is dose-dependent. The comparative } \\
\text { result shows a lower hemolytic activity of } \\
\text { GS than that of GO. GS generates more } \\
\text { reactive oxygen species (ROS) in human } \\
\text { skin fibroblast cells and is strongly } \\
\text { associated with the cell surface. }\end{array}$ & $\begin{array}{l}\text { (Liao et al., } \\
\text { 2011) }\end{array}$ \\
\hline $\begin{array}{l}\text { Graphene } \\
\text { Nanoparticles } \\
\text { (GNPs) }\end{array}$ & $\begin{array}{l}\text { No } \\
\text { information }\end{array}$ & $\begin{array}{l}\text { Average } \\
\text { hydrodynamic } \\
\text { diameter } 323.3 \mathrm{~nm} \\
\text { and width in the } \\
\text { aqueous suspension } \\
80.05 \mathrm{~nm}\end{array}$ & $\begin{array}{l}\text { Epithelial cells } \\
\text { of Human lung } \\
\text { (A549) }\end{array}$ & $\begin{array}{l}(0.1-1000) \\
\mu \mathrm{g} / \mathrm{ml}\end{array}$ & $(24-72) \mathrm{h}$ & $\begin{array}{l}\text { Assessment of } \\
\text { viability of } \\
\text { A549 in GNPs. }\end{array}$ & $\begin{array}{l}\text { The toxicity of GNPs over A549 is } \\
\text { concentration and time-dependent. } \\
\text { Furthermore, exposure of GNPs on } \\
\text { human epithelial cells of the lung for } 72 \\
\text { h, is more lethal than exposure for } 24-48 \\
\text { h. }\end{array}$ & $\begin{array}{l}\text { (Nasirzadeh et } \\
\text { al., 2019) }\end{array}$ \\
\hline $\begin{array}{l}\text { Pristine } \\
\text { graphene }\end{array}$ & $-20.08 \mathrm{mV}$ & $\begin{array}{l}\text { Average diameter } \\
172.7 \pm 75.6 \mathrm{~nm} \text { and } \\
\text { thickness } 2-3 \mathrm{~nm}\end{array}$ & $\begin{array}{l}\text { Murine RAW } \\
264.7 \\
\text { macrophages }\end{array}$ & $20 \mu \mathrm{g} / \mathrm{ml}$ & $24 \mathrm{~h}$ & $\begin{array}{l}\text { Quantification } \\
\text { of cytokines } \\
\text { and } \\
\text { chemokines. }\end{array}$ & $\begin{array}{l}\text { Exposure of macrophages to PG increases } \\
\text { the secretion of Th1/Th2 cytokines by } \\
\text { activating the NF- } \mathrm{KB} \text { signaling pathway. }\end{array}$ & $\begin{array}{l}\text { (Zhou et al., } \\
\text { 2012) }\end{array}$ \\
\hline $\begin{array}{l}\text { Pristine } \\
\text { graphene }\end{array}$ & $\begin{array}{l}\text { No } \\
\text { information }\end{array}$ & $\begin{array}{l}\text { Thickness is } 2-3 \mathrm{~nm} \\
\text { and the size is } 500- \\
1000 \mathrm{~nm}\end{array}$ & $\begin{array}{l}\text { Murine RAW } \\
264.7 \\
\text { macrophages }\end{array}$ & $(5-100) \mu \mathrm{g} / \mathrm{ml}$ & $48 \mathrm{~h}$ & $\begin{array}{l}\text { Triggering of } \\
\text { apoptosis in } \\
\text { macrophages } \\
\text { by pristine }\end{array}$ & $\begin{array}{l}\text { PG induces cytotoxicity by breaking the } \\
\text { mitochondrial membrane potential } \\
\text { (MMP) and increasing intracellular } \\
\text { reactive oxygen species (ROS) levels. It }\end{array}$ & (Li et al., 2012) \\
\hline
\end{tabular}




\begin{tabular}{|c|c|c|c|c|c|c|c|c|}
\hline & & & & & & graphene & $\begin{array}{l}\text { also triggers apoptosis by activation of } \\
\text { the mitochondrial pathway. }\end{array}$ & \\
\hline \multirow[t]{2}{*}{$\begin{array}{l}\text { Graphene } \\
\text { nanoplatelets } \\
\text { (GNPs) }\end{array}$} & $\begin{array}{l}-13 \pm 0.5 \\
\mathrm{mV}\end{array}$ & $\begin{array}{l}\text { Average thickness } \\
220.26 \mathrm{~nm} \text {, average } \\
\text { hydrodynamic radius } \\
243.4 \pm 1.4 \mathrm{~nm}\end{array}$ & $\begin{array}{l}\text { Human } \\
\text { colorectal } \\
\text { adenocarcinoma } \\
\text { cells; Coca-2 } \\
\text { and HT29 }\end{array}$ & $(0-100) \mu \mathrm{g} / \mathrm{ml}$ & $24 \mathrm{~h}$ & $\begin{array}{l}\text { Cytotoxicity } \\
\text { assessment }\end{array}$ & $\begin{array}{l}\text { Cell viability remains approximately the } \\
\text { same at all concentrations of GNPs and } \\
\text { no severe cytotoxic effect of GNPs on } \\
\text { Coca- } 2 / \text { HT } 29 \text { cells has been reported. }\end{array}$ & (Do et al., 2020) \\
\hline & & & & $(5-50) \mu \mathrm{g} / \mathrm{ml}$ & $24 \mathrm{~h}$ & $\begin{array}{l}\text { Genotoxic } \\
\text { damage, } \\
\text { intracellular } \\
\text { oxidative stress } \\
\text { induction }\end{array}$ & $\begin{array}{l}\text { DNA damage has been detected with a } \\
\text { comet assay. Initiation of genotoxic } \\
\text { damage and expression of the ROS- } \\
\text { related gene were GNPs concentration- } \\
\text { dependent. }\end{array}$ & \\
\hline $\begin{array}{l}\text { Pristine } \\
\text { graphene } \\
\text { (PG) and } \\
\text { functionalized } \\
\text { graphene } \\
\text { (FG) }\end{array}$ & $\begin{array}{l}\text { No } \\
\text { information }\end{array}$ & $\begin{array}{l}\text { Average thickness } \\
\approx 0.4 \mathrm{~nm}, \quad \text { double- } \\
\text { layered }\end{array}$ & $\begin{array}{l}\text { Murine } \\
\text { macrophage } \\
\text { cells (RAW } \\
264.7 \text { and } \\
\text { human primary } \\
\text { blood } \\
\text { components }\end{array}$ & $(0-75) \mu \mathrm{g} / \mathrm{ml}$ & $3 \mathrm{~h}$ & $\begin{array}{l}\text { Inflammation } \\
\text { analysis, ROS } \\
\text { production, and } \\
\text { induction of } \\
\text { apoptosis }\end{array}$ & $\begin{array}{l}\text { PG induces higher cytokines production } \\
\text { than FG. In addition, PG showed greater } \\
\text { anti-inflammatory potential than FG. } \\
\text { Apoptosis increased when PG has } \\
\text { changed to FG by surface } \\
\text { functionalization. Furthermore, PG } \\
\text { enhances the formation of ROS. }\end{array}$ & $\begin{array}{l}\text { (Sasidharan et } \\
\text { al., 2012) }\end{array}$ \\
\hline \multirow[t]{2}{*}{$\begin{array}{l}\text { Pristine } \\
\text { graphene, } \\
\text { Lower } \\
\text { Oxygen } \\
\text { Graphene } \\
\text { (LOG), } \\
\text { Higher } \\
\text { Oxygen } \\
\text { Graphene } \\
\text { (HOG) }\end{array}$} & $\begin{array}{l}\text { No } \\
\text { information }\end{array}$ & $\begin{array}{l}\text { The particle size of } \\
\text { pristine graphene is } \\
349 \pm 24 \mathrm{~nm} \text {, LOG } \\
423 \pm 9 \mathrm{~nm} \text {, and HOG } \\
265 \pm 48 \mathrm{~nm}\end{array}$ & PC-12 Cell line & $(5-100) \mu \mathrm{g} / \mathrm{ml}$ & $24 \mathrm{~h}$ & $\begin{array}{l}\text { Cell viability, } \\
\text { cell toxicity, } \\
\text { dispersion in } \\
\text { the cellular } \\
\text { membrane, and } \\
\text { LDH assay }\end{array}$ & $\begin{array}{l}\text { PG is the most cytotoxic and toxicity } \\
\text { decreases with increasing oxygen content. } \\
\text { At higher concentrations of PG ( } 50 \mu \mathrm{g} \text { and } \\
100 \mu \mathrm{g} \text { ), the metabolic activity of viable } \\
\text { cells has significantly reduced. HOG and } \\
\text { GO showed almost identical cytotoxic } \\
\text { results that were two-fold less than LOG. } \\
\text { The induction of LDH secretion is due to } \\
\text { the breakdown of the cell membrane by } \\
\text { graphene nanoparticles. }\end{array}$ & $\begin{array}{l}\text { (Majeed et al., } \\
\text { 2017) }\end{array}$ \\
\hline & & & & $(0.5-5) \mu \mathrm{g} / \mathrm{ml}$ & $2 \mathrm{~h}$ & $\begin{array}{l}\text { Quantification } \\
\text { of Reactive } \\
\text { Oxygen Species } \\
\text { (ROS) }\end{array}$ & $\begin{array}{l}\text { Oxidized graphene generates higher ROS } \\
\text { levels than PG and the aggregation of } \\
\text { pristine on the cell membrane facilitates } \\
\text { the formation of ROS. }\end{array}$ & \\
\hline
\end{tabular}


Figure 1

The structure of the graphene family

(a) Pristine graphene (PG) does not possess functional groups. (b) Graphene oxide (GO) contains several functional groups for binding. (c.) Reduced graphene oxide (rGO) possesses few active functional moieties for binding to composite materials.

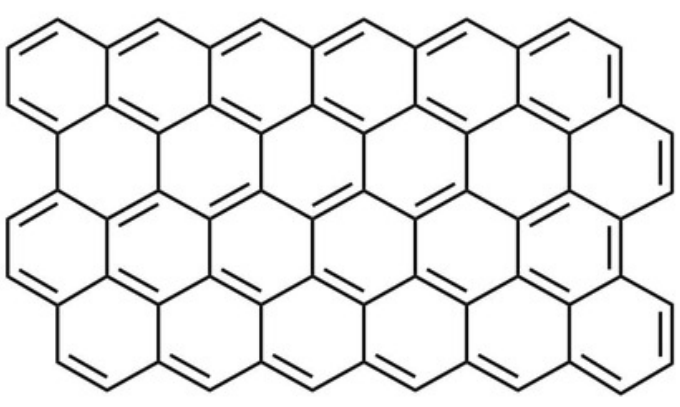

[a]

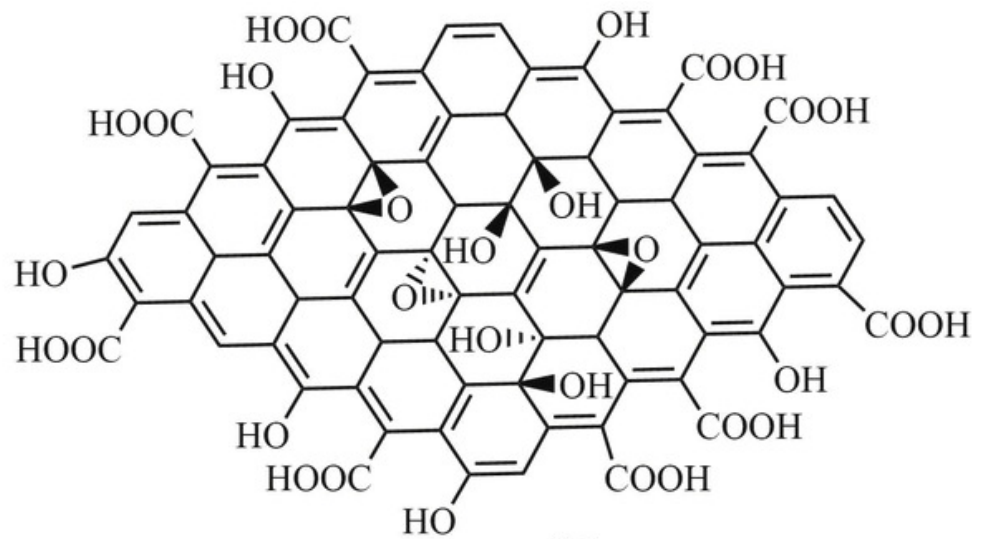

[b]

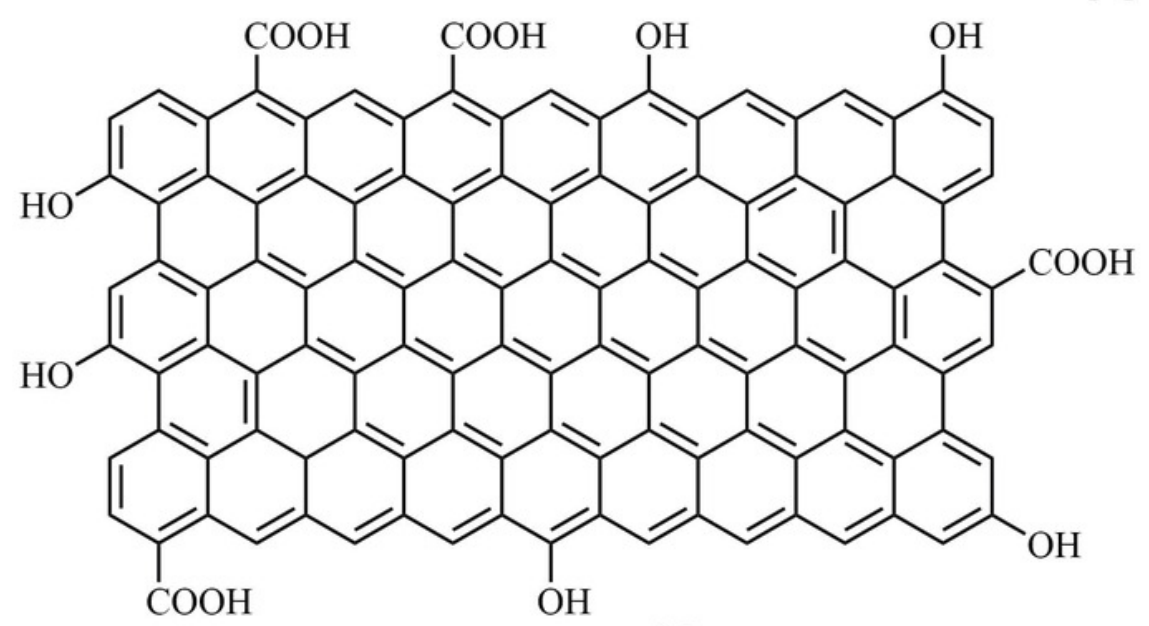

[c] 


\section{Figure 2}

Graphene face mask showing filtration of aerosolized particles in the presence of sunlight.

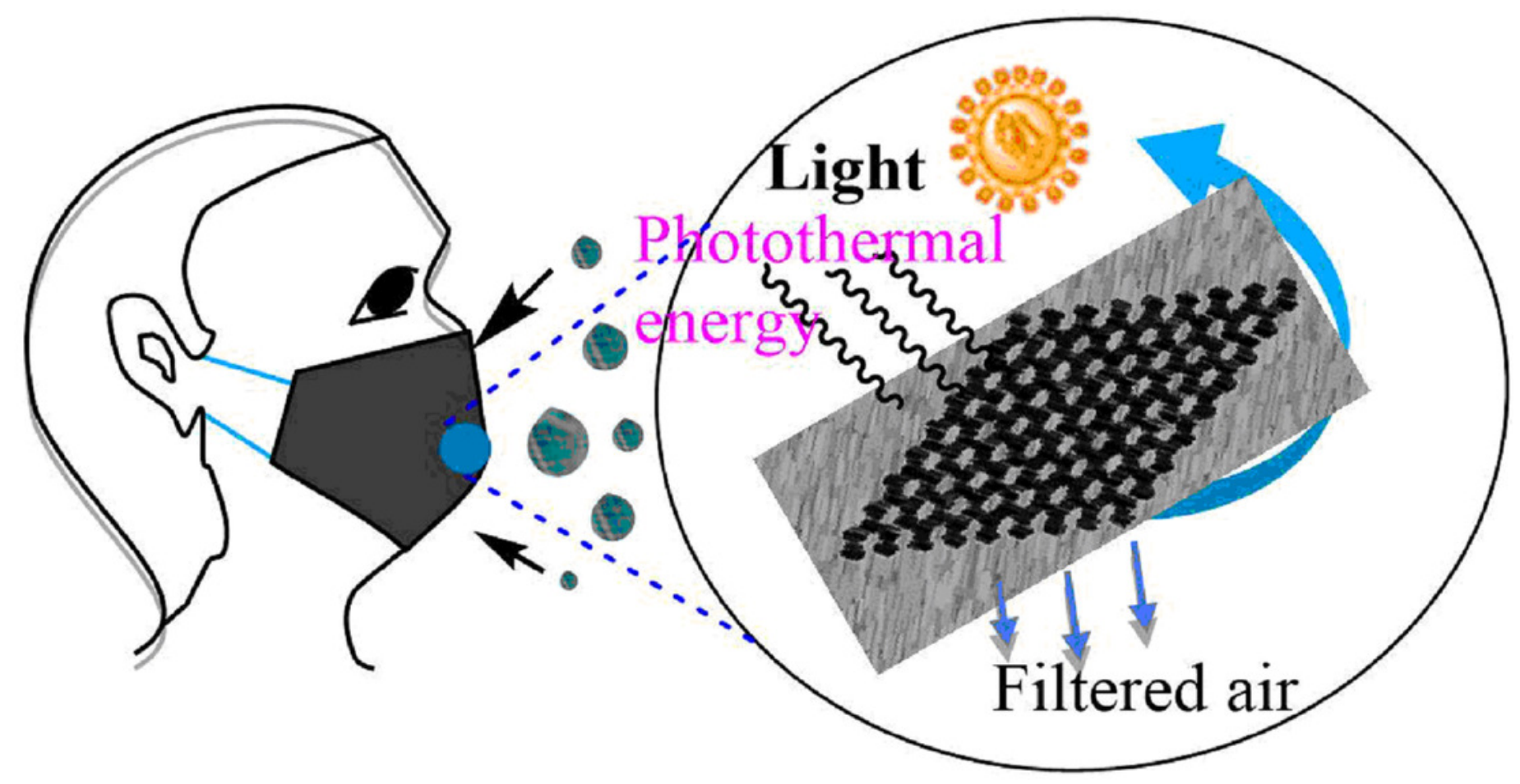


Figure 3

An Overview of various physico-chemical parameters affecting the toxicity of graphene nanomaterials.

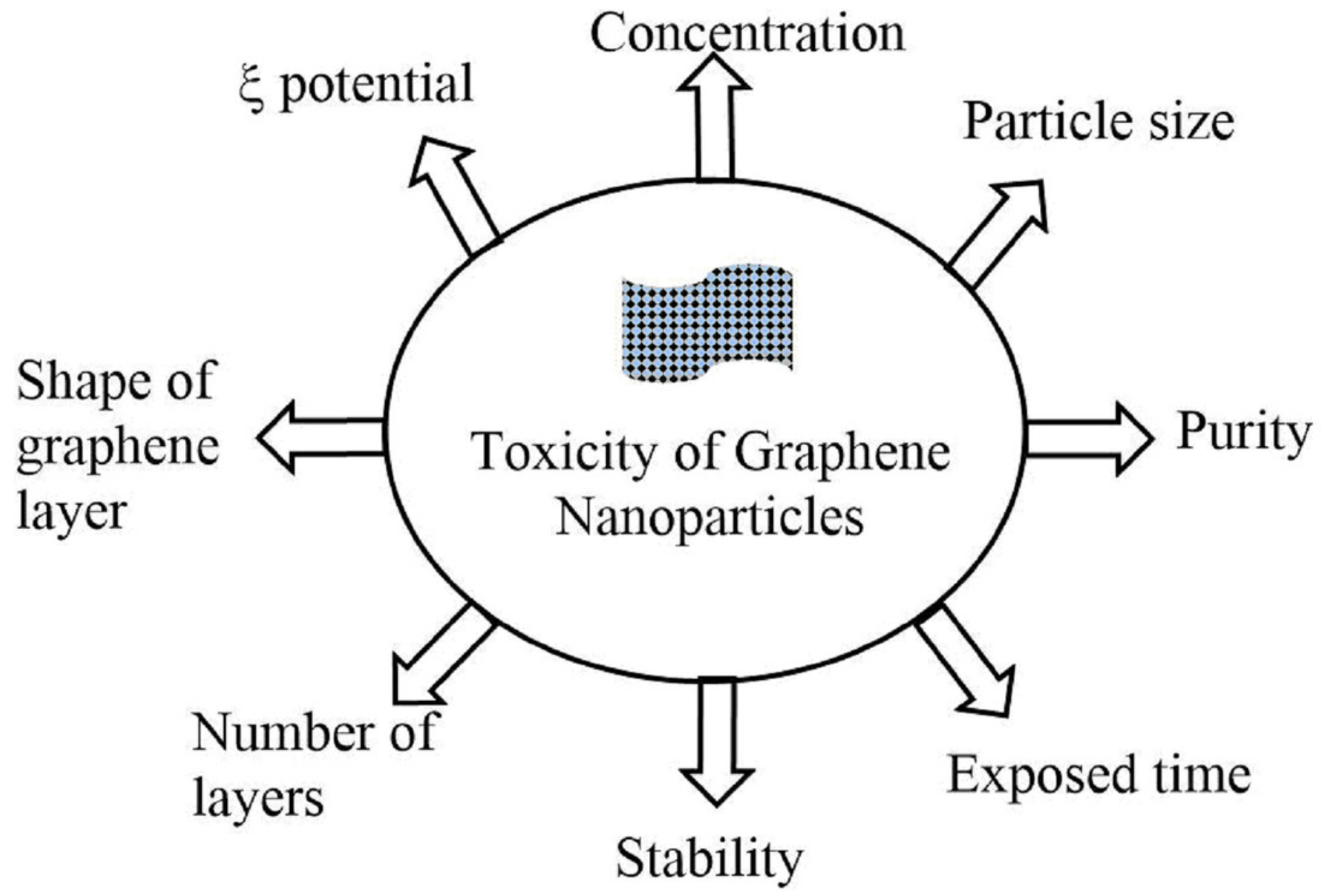




\section{Figure 4}

An illustration showing the filtering efficiency of graphene-based face masks

(A) Graphene materials trap microorganisms by the electrostatic force of attraction. (B)

Electrothermally active graphene face masks inactivate harmful viruses more effectively. (C)

A cloth-mounted graphene membrane can destroy the protein envelope of the virus in presence of IR radiation. (D) The average diameter of graphene nanopores is smaller than the size of the SARS-CoV-2 virus.

Trapping of microorganisms on graphene layer by mutual electrostatic attractive force

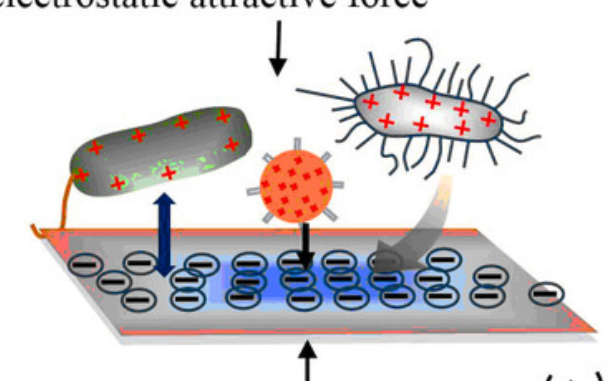

Negatively charged layer of embedded graphene nano flakes on cotton facemask
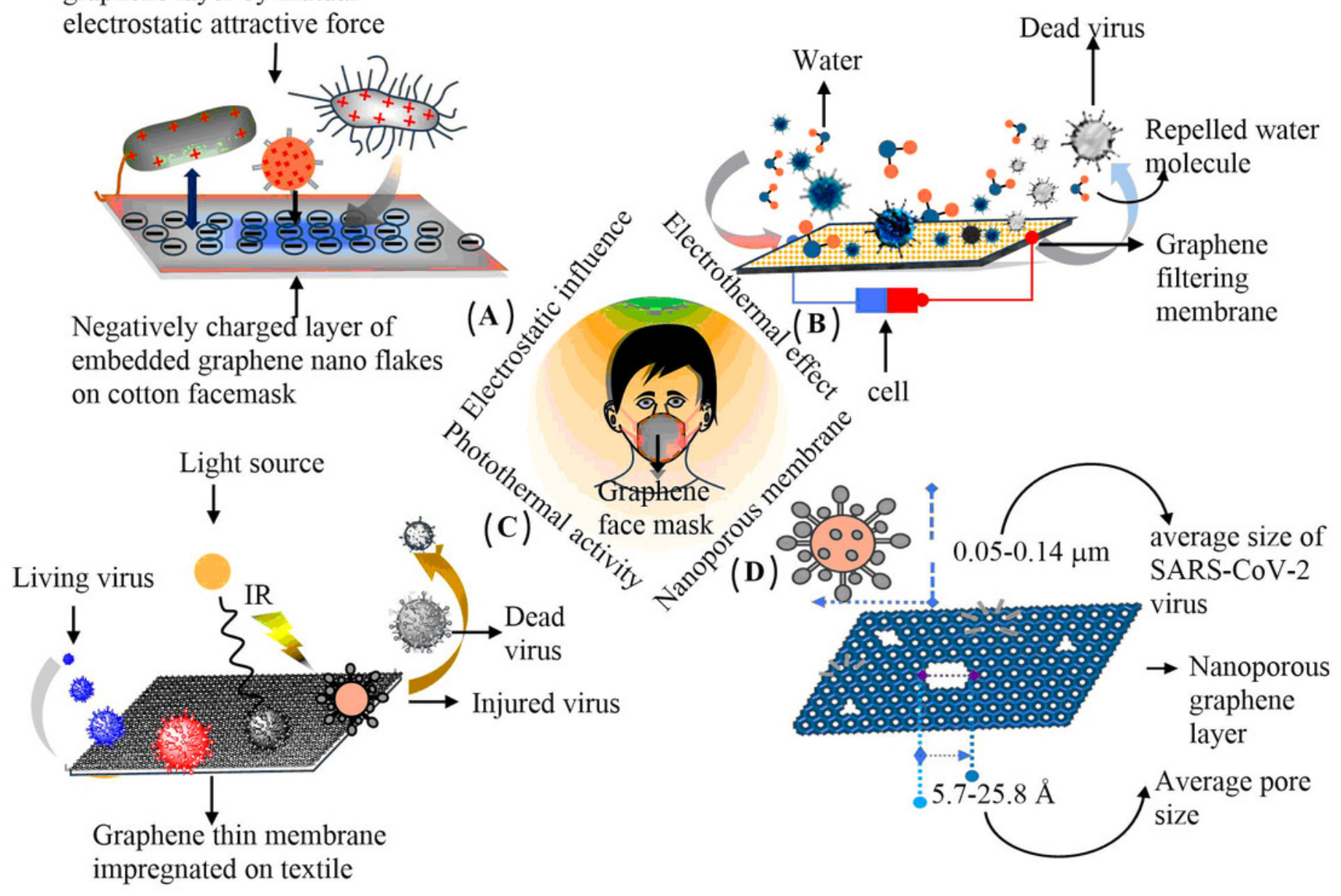


\section{Figure 5}

Schematic illustration of graphene engineered face mask showing the physical and mechanical features 


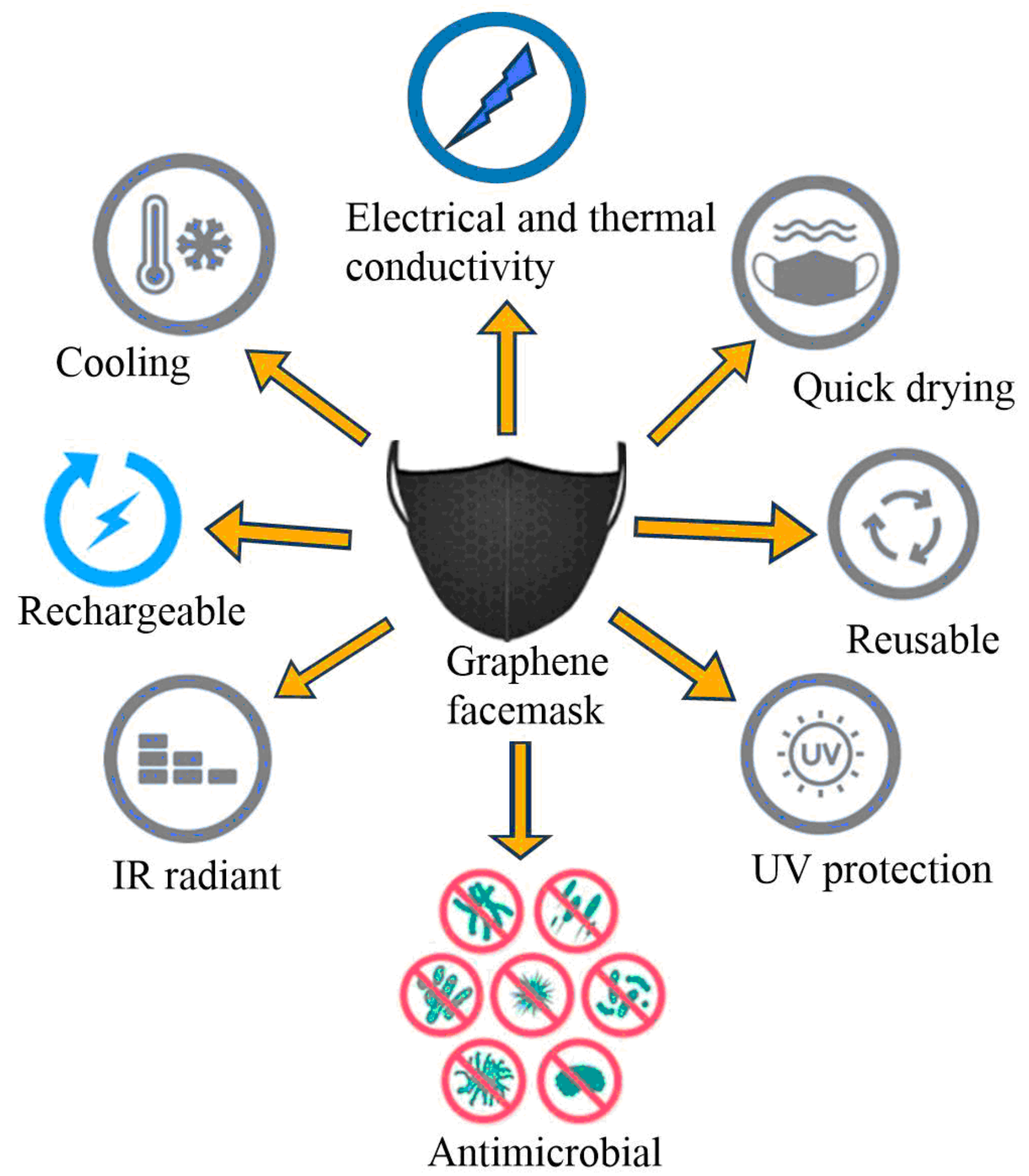


Figure 6

Proposed oral and nasal routes of entering graphene nanoflakes in lungs and blood vessels.

The graphene nanoparticles reach inside the blood vessel by rupturing the inner lining of alveolar epithelial cells and initiate the problem of hemotoxicity, thrombogenicity, anaphylactic reaction, and escalation of IgE level.

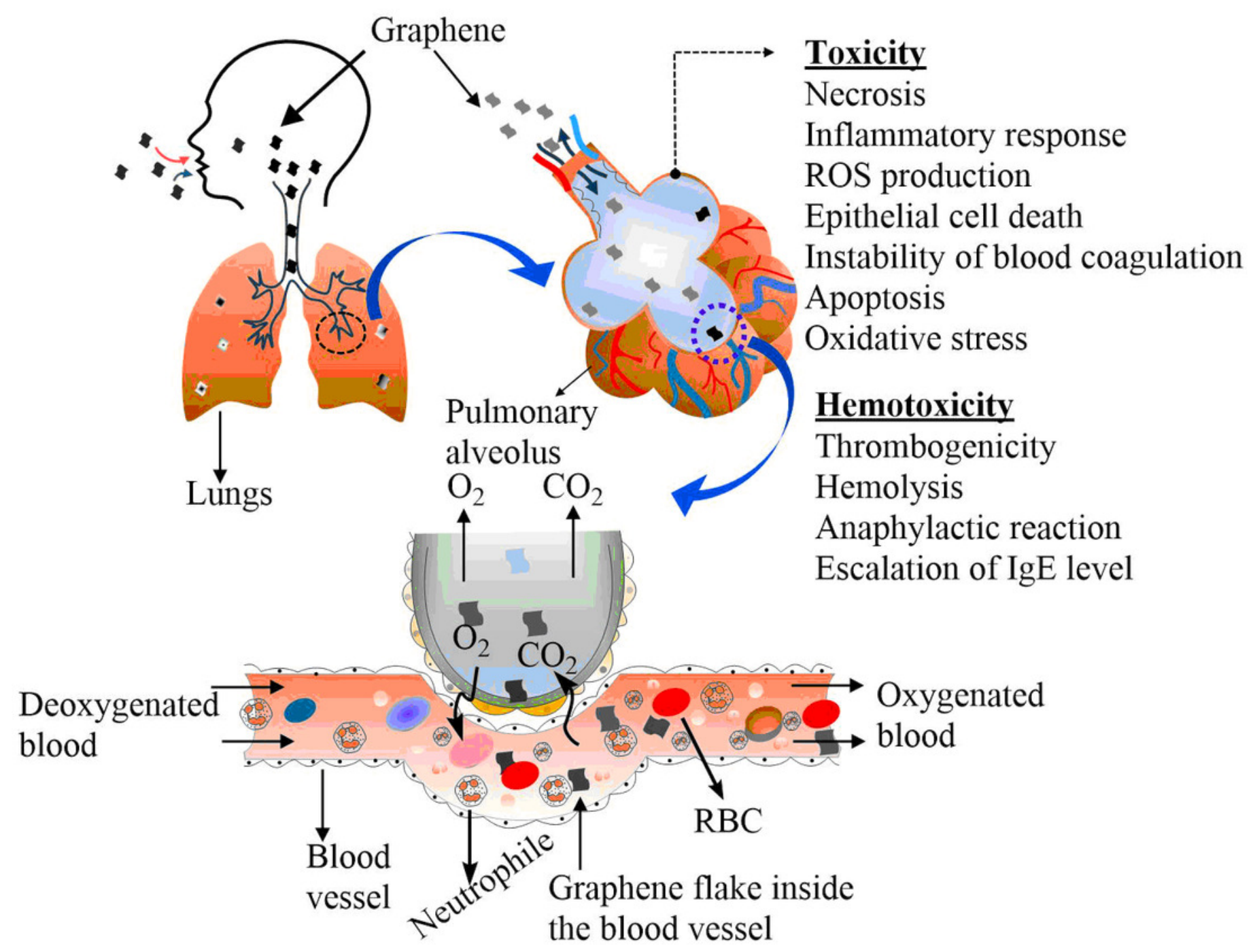

